\title{
A Review of the Synthesis and Applications of Polymer-Nanoclay Composites
}

\author{
Feng Guo ${ }^{1}$, Saman Aryana ${ }^{1, *}$, , Yinghui Han ${ }^{2, *}$ and Yunpeng Jiao ${ }^{2}$ \\ 1 Department of Chemical Engineering, University of Wyoming, Laramie, WY 82072, USA; fguo@uwyo.edu \\ 2 Department of Mathematics and Physics, North China Electric Power University, Baoding 071003, China; \\ ry_jiao@163.com \\ * Correspondence: saryana@uwyo.edu (S.A.); yinghuihan@ncepu.edu.cn (Y.H.); \\ Tel.: +1-307-766-1992 (S.A.); +86-312-752-5093 (Y.H.)
}

Received: 30 August 2018; Accepted: 13 September 2018; Published: 19 September 2018

\begin{abstract}
Recent advancements in material technologies have promoted the development of various preparation strategies and applications of novel polymer-nanoclay composites. Innovative synthesis pathways have resulted in novel polymer-nanoclay composites with improved properties, which have been successfully incorporated in diverse fields such as aerospace, automobile, construction, petroleum, biomedical and wastewater treatment. These composites are recognized as promising advanced materials due to their superior properties, such as enhanced density, strength, relatively large surface areas, high elastic modulus, flame retardancy, and thermomechanical/optoelectronic/magnetic properties. The primary focus of this review is to deliver an up-to-date overview of polymer-nanoclay composites along with their synthesis routes and applications. The discussion highlights potential future directions for this emerging field of research.
\end{abstract}

Keywords: polymer-nanoclay composites; synthesis; applications

\section{Introduction}

Based on their chemical composition and particle morphology, clays are organized into several classes such as smectite, chlorite, kaolinite, illite and halloysite [1]. Due to their wide availability, relatively low cost and relatively low environmental impact, nanoclays have been studied and developed for various applications [2]. With the rapid growth of nanotechnology, clay minerals are increasingly used as natural nanomaterials [3]. Nanoclays are nanoparticles of layered mineral silicates with layered structural units that can form complex clay crystallites by stacking these layers [4]. An individual layer unit is composed of octahedral and/or tetrahedral sheets [5]. Octahedral sheets consist of aluminum or magnesium in a six-fold coordination with oxygen from a tetrahedral sheet and with hydroxyl. Tetrahedral sheets consist of silicon-oxygen tetrahedra linked to neighboring tetrahedra, sharing three corners while the fourth corner of each tetrahedron sheet is connected to an adjacent octahedral sheet via a covalent bond [6], see Figure 1. The arrangements of these sheets impact various defining and distinguishing aspects of nanoclays. Based on their mineralogical composition, there are approximately 30 different types of nanoclays, which depending on their properties are used in different applications [7]. As shown in Table 1, three major 1:1, 2:1 and 2:1:1 sheet arrangements are observed in common nanoclay materials. In 1:1 structures, each tetrahedral is connected to one octahedral sheet; in 2:1 structures, each octahedral sheet is connected to two tetrahedral sheets (one sheet on each side); and in 2:1:1 structures, each octahedral sheet is adjacent to another octahedral sheet and connected to two tetrahedral sheets $[8,9]$. For example, Halloysite nanoclay is a naturally occurring aluminosilicate nanotube with the average dimensions of $15 \mathrm{~nm} \times 1000 \mathrm{~nm}$ [10]. Due to the hollow tube structure, halloysite nanoclay (1:1 nanotube) is used for medical applications, food packaging and 
rheology modification [11]. The most common plate-like montmorillonite (MMT) nanoclay (smectite) consists of approximately one nm thick aluminosilicate layers surface-substituted with metal cations and stacked in approximately $10 \mu \mathrm{m}$-sized multilayer stacks [12]. The stacks can be dispersed in a polymer matrix as fillers/additives to form polymer/nanoclay composites, with applications such as mechanical strength enhancement, flame-resistance material, thickening and gelling agents, waste water treatment and gas permeability modification [12-15]. MMT nanoclay (2:1 layered silicates) with a high cation exchange capacity has cation exchange sites on the siloxane surface which can be combined with dissimilar substances, such as organic or biological molecules [16]. The MMT nanoclay stacks can be dispersed in a polymer matrix as fillers/additives to form polymer/nanoclay composites, which have been widely studied due to their high cation exchange capacity, swelling behavior, and large surface area [17-19]. Halloysite nanoclays are readily dispersed in various polymers without the need for exfoliation. This is due to there being less abundant hydroxyl groups on the nanoclay surfaces compared to MMTs. Additionally, tubular halloysite nanoclays are excellent nanocontainers for various chemical molecules [20]. Thus, the functionalized halloysite nanoclays are employed as efficient fillers for polymers to enhance their mechanical and thermal properties. These nanoclays are also used as carriers to achieve a sustained release of active molecules, such as flame-retardants, antioxidants, anticorrosion and antimicrobial agents [21,22]. The research and development of novel polymer/nanoclay materials has been an advancing field in material chemistry in recent years [9,12-15,23-25]. Rigid nanoclay may be used as a filler and is able to reinforce polymer structures and impede the free movement of polymer chains neighboring the filler [19]. Moreover, it behaves as a load-bearing constituent when the interfacial adhesion between the filler and the chains is fulfilled [26].

Two crucial challenges of synthesis are to achieve: (1) chemical compatibility between the polymer matrix and the nanofiller at the nanoscale; and (2) homogeneous dispersion of the nanofiller within the polymer matrix. The interfacial interaction between nanoclay fillers and polymer matrix, as well as the quality of nanoclay dispersion, has a significant influence on the performance of polymer/nanoclay composites [27]. These intercorrelated features determine the polymer/nanoclay composites' morphology and, thus, their final bulk properties such as strength, elastic modulus, thermal stability, heat distortion temperature, self-healing, shape memory abilities and gas barrier [28,29]. The surface functionalization of nanoclays is a practical method to enhance the interfacial interactions between nanoclay fillers and polymeric matrix, enabling the transfer of interfacial stress from the polymer to the nanoclays [30]. For instance, the covalent modification of the outer surfaces of halloysite nanotubes enhances their dispersibility into the polymer matrix, which may improve the thermal stability and tensile properties of the resulting polymer/nanoclay composites [31]. Synthesis approaches may lead to different combinations of polymer matrix and nanoclays, such as an immiscible structure, an intercalated structure and an exfoliated structure [32]. In the immiscible structure, the nanoclay dispersion aggregates within the polymer matrix and the polymers are separated from the clay layers [33]. The polymer chains form an intercalated structure between the clay layers, altering the geometry of the clay layers. This alternation includes variation in the stacking mode of the layers, modification in interlayer spacing, and diminishing the electrostatic forces between the clay layers, which lead to greater enhancement of the mechanical and thermal properties of the composites [34-36]. Nanoclay stacks are fully separated by polymer chains in the exfoliated structure, providing superior mechanical properties and polymer processability [37]. There are three major synthesis procedures for polymer/nanoclay composites including the melt-blending method, solution-blending method and in-situ polymerization method [6]. Heretofore, the most widely applied synthesis method was the in-situ polymerization method, where the grafted amounts of organics was adjusted and the clay interlayer spacing was controlled by changing the polymerization conditions [38]. The combination of in-situ polymerization with efficient coupling methods, including click chemistry [39], radical-mediated polymerization [40,41], tandem preparation [42], photopolymerization [38] and miniemulsion [43], has enabled effective dispersion of nanoclays in the form of individual platelets in 
the polymer matrix, which is a significant challenge inherent to the synthesis of polymer/nanoclay composites. All these methods have been successfully implemented for the chemical modification of clay surfaces with low molecular or polymeric grafts [44].

Polymer/nanoclay composites have been expanded to several hybrid, innovative materials including nanoclay/conductive polymer (polypyrrole (PPy), polyaniline (PANI), polythiophene (PT), and poly(3,4-ethylenedioxythiophene) (PEDOT), biocomposites and organoclay hybrid films with properties superior to conventional composite materials [45]. These novel composites are attained with a lower modified nanoclay filler content in comparison to conventionally filled systems and are, as a result, lighter in weight [46]. Due to their unique properties, polymer/nanoclay composites have been used in a number of industrial applications, such as construction (building sections and structural panels), automotive (gas tanks, bumpers, interior and exterior panels), chemical processes (catalysts), pharmaceutical (as carriers of drugs and penetrants), aerospace (flame retardant panels and high performance components), food packaging and textiles [47]. Limitations in fossil resources and an urgent need to protect the environment have led to new generations and applications of polymer/nanoclay composites. Innovative bioinspired polymer/nanoclay composite materials are expected to find applications in various scientific and technological fields [48].

This article presents a review of recent advances in the synthesis and novel applications of polymer/nanoclay composites. It provides an up-to-date summary of synthesis methods and applications with a focus on the surface-modified nanoclay fillers, and the potential future scope for composite materials.

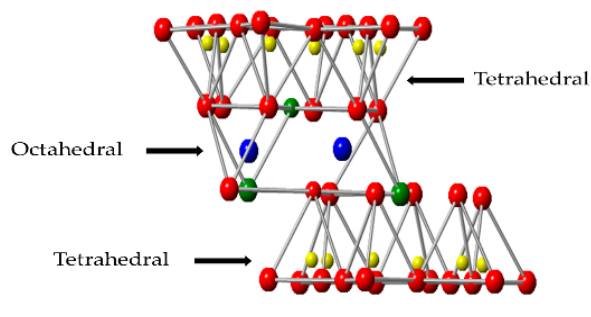

(a)

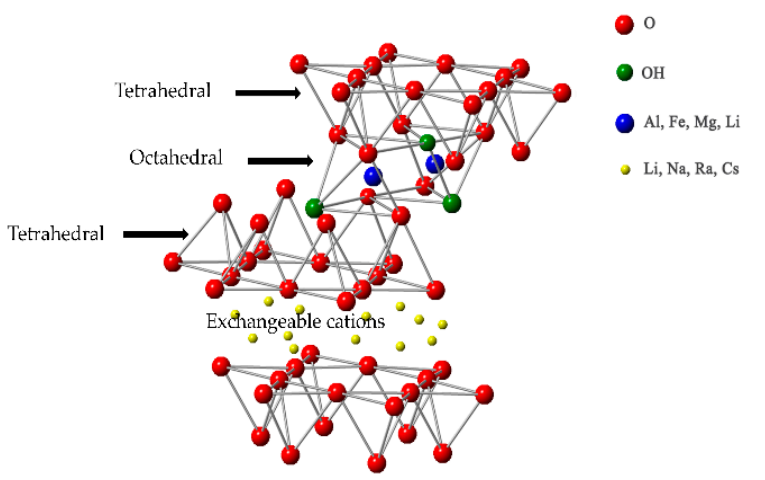

(b)

Figure 1. Crystal structures of clay minerals: (a) Type 1:1; (b) Type 2:1 [49].

Table 1. Classification of clay minerals.

\begin{tabular}{|c|c|c|}
\hline Clay Layer Type & Clay Group & Clay Species \\
\hline $1: 1$ & $\begin{array}{l}\text { Rectorite, Kaolinite, } \\
\text { Halloysite, Chyrsotile }\end{array}$ & $\begin{array}{l}\text { Lizardite, Berthierine, Cronstedtite, Kellyite, } \\
\text { Fraipontite, Brindleyite, Dickite, Nacrite }\end{array}$ \\
\hline $2: 1$ & $\begin{array}{l}\text { Smectite, Vermiculite, } \\
\text { Pyrophylite talc, Mica, } \\
\text { Brittle Mica }\end{array}$ & $\begin{array}{c}\text { Montmorillonite, Laponite, Sepiolite, Hectorite, } \\
\text { Bentonite, Vermiculite, Pyrophyllite, Talc, } \\
\text { Muscovite, Paragonite, Clintonite, Bityite }\end{array}$ \\
\hline $2: 1: 1$ & Chlorite & Amesite, Cookeite \\
\hline
\end{tabular}

\section{Synthesis}

Various approaches are available for each of the three synthesis methods, namely solution-blending, melt-blending and in-situ polymerization. An important task in the preparation of polymer/nanoclay composites is to achieve a uniform dispersion of nanoclay in the polymer matrix. The solution-blending technique often yields favorable dispersion of clay layers in the polymer matrix, in comparison with melt blending, due to its low viscosity and high agitation power. On the other hand, 
melt blending is considered industrially viable and ecofriendly, with high economic potential [50]. The in-situ polymerization method is a widely-applied synthesis technique, which provides uniform dispersion and is easy to modify by changing the polymerization conditions [38]. Recently, a number of novel synthesis approaches have been proposed to design polymer/nanoclay composites with unique properties. In this work, different advanced synthesis approaches are reviewed and relationships between the synthesis strategy, the structure formation, physical and mechanical properties and characteristics of the polymer/nanoclay composites are discussed.

\subsection{Solution-Blending Method}

Solution-blending is a solvent based process in which the polymer and the prepolymer are soluble, which causes swelling of the clay layers, see Figure 2 [51]. The layered clay is exfoliated onto single layers using a solvent in which the polymer or prepolymer is soluble, such as water, chloroform, or toluene [52]. When the polymer/prepolymer and layered clay are mixed in a solution, the polymer chains intercalate and displace the solvent within the interlayer of the clay [53]. Upon solvent removal (by vaporization or precipitation), the intercalated sheets reassemble, resulting in polymer/nanoclay composites [53]. The driving force of intercalation in solution blending is the entropy gained from desorption of solvent molecules [54]. The entire process typically consists of three stages, namely the dispersion of clay in a polymer solution, controlled removal of the solvent, and finally, composite film casting [53]. The dispersion of clay requires energetic agitation such as stirring, reflux and shear mixing. Recently, ultrasonication has become an efficient approach to improve the dispersion of nanoclays in a polymer solution, by breaking up nanoclay clusters through cavitation in the solution and/or exciting resonance vibrations of the clusters. Nanoclay contents, sonication type (bath or tip), solvent type, and sonication time impact the quality of the dispersion of nanoclays in the polymer solution [52]. Ultrasonication is applicable for processing both thermoplastic and thermoset polymers [55]. For instance, Cherifi et al. [37] modified Algerian clay using ultrasonication and synthesized poly-glycidyl methacrylate (GMA)/nanoclay composites. The results confirmed the intercalation of surfactants within the clay layers and the composites exhibited significant improvement in their thermal stabilities compared to unmodified poly-GMA. Ultrasonication appears to offer several advantages in terms of reaction time, clay dispersion and polymer/nanoclay composite yield [56]. Buruga et al. [57] synthesized a halloysite nanoclay-based poly(methyl methacrylate) (PMMA) and polystyrene (PS) composite using an ultrasound-assisted, solution blending method. Various glass surfaces were coated with the synthesized composites, which resulted in the improved scratch resistance and hydrophobicity of the surfaces. The enhanced thermal and mechanical properties of these composites were attributed to the highly dispersed nature of halloysite nanoclay fillers. Removal of the solvent also plays a critical role in the physical properties of the polymer/nanoclay composites; slow evaporation of the solvent may yield a composite with a high polymer crystallinity [56]. The solution blending method is usually used to prepare thermoplastic and thermoset composites (epoxy composites) at the laboratory scale due to its easy operation, excellent particle dispersion, and coupling chemical reactions [55]. Meanwhile, several studies, such as that by López-Manchado et al. [58] have shown the possibility of preparing intercalated or exfoliated rubber composites. In their study, rubber/MMT composites were prepared using solution blending and the structure and properties of the prepared composites were compared with composites produced via melt blending. The results indicated that solution blending delivers a similar composite structure, yields a higher amount of bound rubber, and enhances the compression set, hardness and dynamic mechanical properties. Maiti et al. [59] synthesized exfoliated ethylene-octene copolymer/MMT composites using a solution blending technique, which improved the tensile modulus by $63 \%$, tensile strength by $44 \%$, storage modulus by $14 \%$ and resulted in a $10{ }^{\circ} \mathrm{C}$ shift in glass transition temperature compared to the neat copolymer. Hausner et al. [60] utilized a highly volatile organic separator solvent to generate PS/MMT composites at melt compounding temperatures (transfer batch blending). This innovative solution blending method produces a solid-state composite at room temperature, allowing easy removal, handling 
and processing. Arya et al. [61] synthesized magnetic polymer/nanoclay composites using solution blending to remove three pharmaceutical pollutants, namely atenolol, ciprofloxacin and gemfibrozil. Their study indicated that the maximum adsorption was obtained when the composite is at the optimum ratio (clay:chitosan:powdered activated carbon:magnetic nanoparticles) of 1:0.5:0.3:0.3. He et al. [62] prepared PS/exfoliated graphite nanoplate composites via the solution blending method assisted by ultrasonication. The produced composites exhibited an enhanced and stable dielectric constant, which was attributed to the proper dispersion of graphite nanoplates in the PS matrix. Lago et al. [63] improved the mechanical and electrical properties of polycarbonate-based graphene composites using a simple and scalable solution blending method. A solvent-exchange process was carried out to re-disperse the exfoliated graphene flakes in an environmentally friendly solvent (1,3-dioxolane). The resulting composite is a promising material for 3D-printing-based applications. Abbasian et al. [64] employed well-defined, polymerically-modified clay nanoparticles for the preparation of PS composite by nitroxide-mediated radical polymerization and solution blending methods. This approach produced exfoliated or mixed intercalated/exfoliated composites. Alver et al. [65] prepared polymer/zeolite composite beads by a simple solution blending method using chitosan, polyvinylpyrrolidone and zeolite particles. The synthesized composite beads had relatively large loading capacities for heavy metals, making them a promising material for water treatment applications.

Solution blending produces relatively uniform nanoclay dispersions and a number of polymer/nanoclay composites have been produced to date, see Table 2. This method has several drawbacks: (1) the intercalation process only occurs for certain polymer/clay/solvent combinations; and (2) copious amounts of organic solvents are typically required, which may be environmentally unfriendly and economically prohibitive [66]. At commercial scales, melt blending is preferred over solution mixing for the preparation of thermoplastic/nanoclay composites.

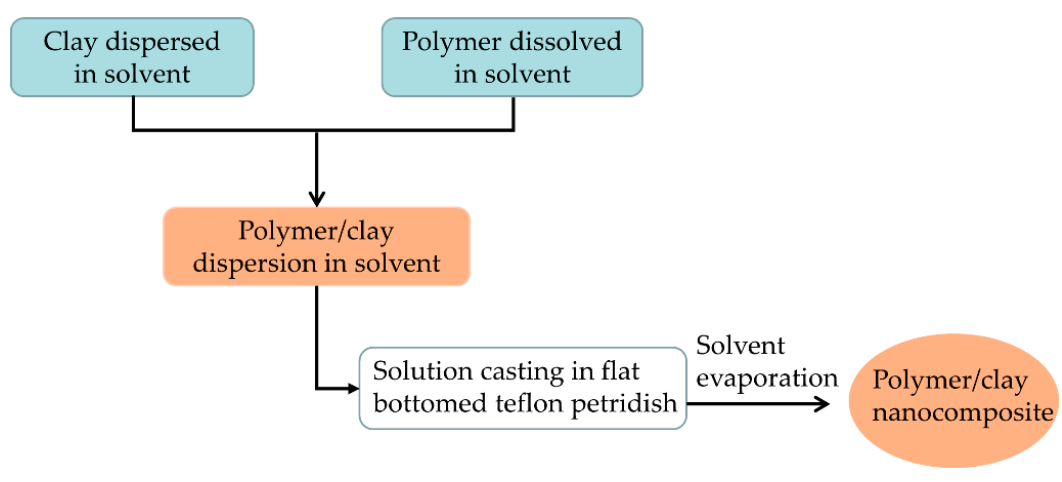

Figure 2. Solution-blending method scheme.

Table 2. Polymer/nanoclay composite made by solution blending. All these composites have an intercalated clay structure. PS: polystyrene.

\begin{tabular}{ccc}
\hline Nanoclay & Polymer & Reference \\
\hline Co-Al-LDH & PS & {$[67]$} \\
Cloisite $^{\circledR}$ 30B & Chitosan/polylactide & {$[68]$} \\
Mg-Al-LDH & Epoxy & {$[69]$} \\
Mg-Al-LDH & Acrylic resin & {$[70]$} \\
Cloisite and sepiolite & Hydrogenated nitrile butadiene rubber & {$[71]$} \\
\hline
\end{tabular}

\subsection{Melt-Blending Method}

The melt-blending method blends the desired amount of intercalated nanoclay particles with polymers at a temperature above the polymers' softening point in the presence of an inert gas [72-75] (Figure 3). The melt-blending method provides better mixing of the polymer and nanoclay fillers compared to the solution-blending method and is compatible with current industrial processes such as 
extrusion and injection molding, particularly for thermoplastic and elastomeric material fabrication [33]. The absence of solvents reduces the environmental impact and minimizes potential interactions between the host and polymer solvents, which, in many cases, limits clay dispersion [76]. The melting conditions, such as feed rate, temperature profile, rotor/screw speed, mixing time, oxidative environment, die pressure, material grades and contents, as well as the chemical nature of the nanoclay filler and polymers, are important parameters for the synthesis of the composites [77]. An enthalpic driving force for the functionalized macromolecules, a relatively large interlayer spacing for the macromolecular Gaussian coil, and sufficient time for the diffusion process of the center-stacked layers are three essential elements in the melt-blending method [78]. The melt-blending process can either be static or dynamic. In static melt blending (melt annealing), the process is carried out under a vacuum at temperatures of approximately $50{ }^{\circ} \mathrm{C}$ above transition temperatures in the absence of mixing [79]. In dynamic melt blending, the melting is performed in a melt mixer in the presence of an inert gas [80]. Melt mixers are categorized as batch (internal) and continuous (extruder) mixers [81]. A practical mixer provides excellent control over residence time, shear, temperature, and pressure, which are important while compounding heat-sensitive materials or dispersing nanoclay fillers [56]. The common batch mixers are the laboratory type manufactured by Brabender or Haake and their homologues on the large scale are manufactured by Banbury or Moriyama as dispersion mixers. Significant heat conduction by the mixing shafts is an important drawback of these mixers [56]. Recently, several melt mixers were designed to develop novel melt blending processes for advanced thermoplastic and elastomeric polymer/nanoclay composites (Table 3) [82]. Burmistr et al. [83] applied a disk-screw extruder to prepare an organo-bentonite with polyamide, PS and polypropylene (PP) using the melt-blending method. The result showed that organo-MMT layers are well exfoliated and dispersed into the polymer matrix. Poly(methyl methacrylate) (PMMA) composites with an intercalated structure were successfully fabricated by Bee et al. [84] using melt blending with a functionalized pristine sodium MMT and organically-modified Cloisite ${ }^{\circledR}$ 20A (BYK Additives \& Instrument, Wesel, Germany). The composite exhibited superior thermal stability and tensile strength compared to neat PMMA and PMMA/pristine sodium MMT composites. Beuguel et al. [85] used two polyamides (PA 6 and PA 12) to prepare PP/polyamide nanoclay composites by simultaneously melt blending two polyamides and MMT nanoparticles. The MMT clay nanoparticles appeared to be mostly located at the interface and formed a composite interphase. Moustafa et al. [86] developed a biodegradable polymer/nanoclay composite using a novel natureplast PBE 003/poly(butylene adipate-co-terephthalate) with various expanded organoclays by melt blending. The tensile strength of the composites ( $5 \%$ expanded organoclay) showed a good correlation with the properties of the water vapor permeability barrier, making them a promising candidate for food packaging and biomedical applications. Vassiljeva et al. [87] improved the electrical conductivity of the membranes made of styrene-co-acrylonitrile (SAN) reinforced with carbon nanotubes (CNTs) using a one-step reactive melt blending method. The results showed that simple reactive melt blending may improve the tensile stress and dynamic modulus of SAN membranes and the dispersion of CNTs in SAN matrix. Ercan et al. [88] compared the effects of melt blending and solution blending methods on the physical properties of thermoplastic polyurethane/nanoclay composite films; nanoclays exhibited a higher dispersion, exfoliated, and semi-exfoliated structures in the melting blending synthesized samples compared to those from the solution blending experiments. The melt blending method appeared to result in improvements in creep resistance, and the gas and water vapor permeability of polyurethane/nanoclay films. Quigley et al. [89] applied a novel melting blending method using supercritical carbon dioxide $\left(\mathrm{scCO}_{2}\right)$ as a processing aid to exfoliate nanoclays and improved its dispersion after melt blending in nylon 6 matrices. The synthesized nylon 6/nanoclay composites exhibited improved mechanical properties due to favorable interactions between the clay and polymers. Chao et al. [90] modified isotactic polypropylene (iPP) fibers via melt blending in a twin-screw extruder. The preparation process increased the interaction between nano-capsules, the hydrophobic PP matrix and the dispersion of nano-capsules. The study concluded that the incorporated nanoclays showed 
little influence on the crystallization behavior and thermal stability of iPP. Yilmaz et al. [91] applied melt blending to synthesize highly hemocompatible and biocompatible polymer/nanoclay composites using different molecular weights of poly(methyl methacrylate) (PMMA) and different concentrations of nanohydroxyapatite (nHAp). This study investigated the effects of the molecular weight of PMMA on hemocompatibility, cytotoxicity, and genotoxicity of composites, and the polymer/nanoclay composites appeared to have potential uses in clinical applications, particularly in dentistry. The dispersion of nanoclay in rubber polymers is challenging due to its amorphous nature, high viscosity, and low surface energy compared with thermoplastic polymers [2]. Thus, high temperature melt blending with extrusion may be a promising technique [92].

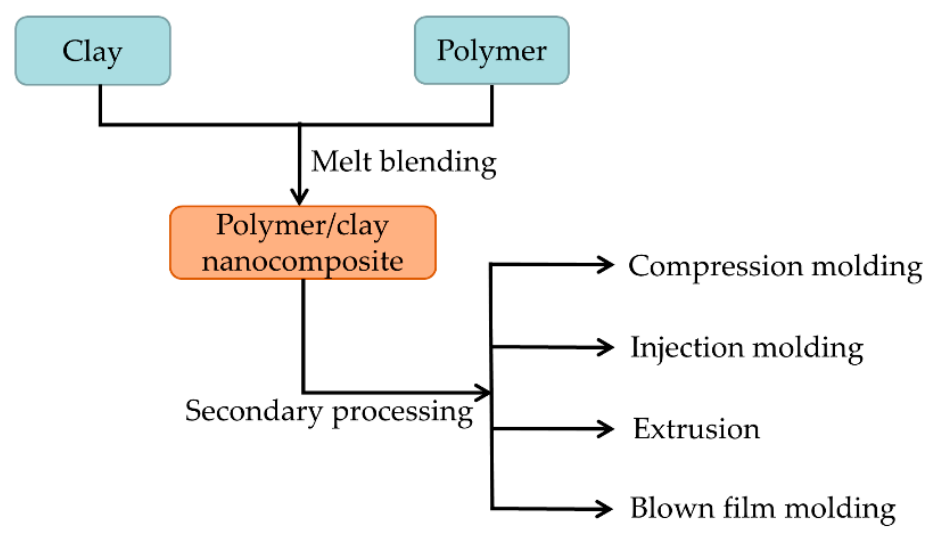

Figure 3. Melt-blending method scheme.

Table 3. Polymer/nanoclay prepared by the melt-blending method and dispersion states. MMT: montmorillonite.

\begin{tabular}{cccc}
\hline Nanoclay & Polymer & Clay Structure & Reference \\
\hline Cloisite $^{\circledR}$ 30B & Nylon 6 & Intercalated & {$[93]$} \\
Na-MMT & Nylon 66 & Disordered & {$[94]$} \\
Na-MMT & Epoxy & Intercalated & {$[95]$} \\
Na-MMT & Polyamide & Exfoliated & {$[96]$} \\
MMT & Polypropylene & Exfoliated & {$[97]$} \\
MMT & Polyvinyl chloride & Exfoliated & {$[98]$} \\
\hline
\end{tabular}

\subsection{In-Situ Polymerization Method}

The melt-blending method often leads to insufficient filler dispersion, which causes aggregation and intercalation, particularly at high filler contents [99]. Based on the silicate dispersion data [100], in-situ polymerization is more effective in the formation of composites, and can bypass the rigorous thermodynamic requirements associated with the polymer intercalation process [101] (Figure 4). Moreover, in-situ polymerization allows versatile molecular designs of the polymer matrix; it delivers an effective approach to the synthesis of different polymer/nanoclay composites with an expanded property range and enables the design of the interface between the nanoclays and the polymers by flexible tuning of the matrix composition and structure [102]. A number of studies focus on preparing novel polymer/nanoclay composites via the in situ polymerization method and demonstrate the benefits of this method in comparison with other types of synthesis methods [103] (Table 4). For instance, Ozkose et al. [34] reported the synthesis of poly(2-ethyl-2-oxazoline)/nanoclay composites for the first time using in-situ polymerization. In their study, a ring-opening polymerization approach was designed, which triggered the delamination of clay layers in the polymer matrix and led to a composite formation. The results exhibited mixed exfoliated/intercalated layers and improved thermal stability compared to pure poly(2-ethyl-2-oxazoline). Zang et al. [104] prepared a conductive composite containing PPy, silver and attapulgite clay using in-situ polymerization; the resulting composites with 
a beads-on-a-string morphology were obtained in 10 minutes. The in-situ polymerization method delivered well-dispersed clay fillers in a polymer matrix, which imparted an outstanding antibacterial property to the biodegradable composite material as well as an enhanced storage modulus. Herrero et al. [105] investigated the influence of the shape and area of the nanoclays used in the in-situ polymerization method. Their study demonstrated that needlelike clay promotes higher molar mass and better mechanical properties compared to laminar clay; they improved the in-situ polymerization process by using a non-isothermal temperature profile and an additional amount of co-catalyst. Kherroub et al. [106] applied direct in-situ polymerization to synthesize poly(furfuryl alcohol)/MMT composites. The produced composites exhibited an intercalated and/or exfoliated structure, which promoted improved thermal stability and mechanical properties compared with pure polymer. Prado et al. [107] synthesized several PMMA/MMT composites by in-situ polymerization and using a chloroform solution under probe sonication. The prepared composites exhibited mixed and intercalated morphologies, which contributed to promising properties for optical electronic devices. Sharma et al. [108] enhanced the thermal and mechanical properties of poly(MMA-co-BA)/Cloisite ${ }^{\circledR}$ 30B (BYK Additives \& Instrument, Wesel, Germany) composites by using an ultrasound-assisted in-situ emulsion polymerization method. This innovative method provided higher thermal degradation resistance and mechanical strength than the composites synthesized using conventional techniques. The composite had a highly exfoliated and dispersed structure due to intense micro-convection induced by ultrasound and cavitation. Compared to the use of the melt-blending method, Cardoso et al. [109] showed an improvement in the mechanical properties and increased the clay basal spacing in the polymeric matrix of PP/MMT composites prepared by in-situ polymerization. Using in-situ polymerization, Hua et al. [110] prepared a rubber/clay composites (cis-1,4-Polybutadiene/MMT) and overcame its mechanical shortcomings, such as low tensile strength, tear resistance and thermal stability. The study demonstrated that Ni-based catalyst systems within the presence of MMT carry a high efficiency and 1,4-selectivity for the polymerization of butadiene. Cherifi et al. [37] also applied ultrasonication as part of the in-situ polymerization method to prepare poly(glycidyl methacrylate)/MMT composites. Compared to solution blending methods, ultrasound-assisted in-situ polymerization resulted in composites with improved reaction time, clay dispersion and composite yield.

This review discusses a number of recent in-situ polymerization routes to the preparation of polymer/nanoclay composites with a specific focus on advanced synthetic methods, such as controlled/living radical polymerization, photopolymerization, click coupling chemistry and emulsion polymerization methods. These methods have been successfully implemented for the chemical modification of clay surfaces with low molecular or polymeric grafts [44].

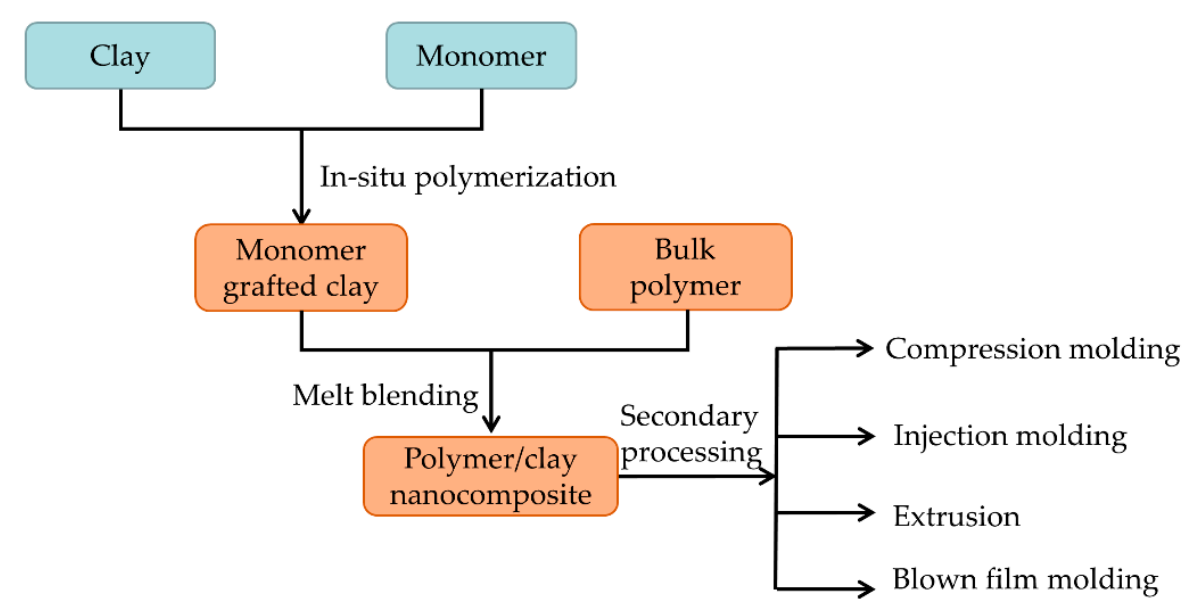

Figure 4. In-situ polymerization method scheme. 
Table 4. Polymer/nanoclay prepared by the melt-blending method and dispersion states. PPy: polypyrrole; PP: polypropylene.

\begin{tabular}{cccc}
\hline Nanoclay & Polymer & Clay Structure & Reference \\
\hline MMT & 2,2,2-trifluoroethyl methacrylate & Exfoliated and intercalated & {$[35]$} \\
Fe-kanemite & PPy & Exfoliated & {$[111]$} \\
MMT & Bisphenol A polycarbonate & Exfoliated & {$[112]$} \\
Vinyl clay & PS & Intercalated & {$[113]$} \\
Sepiolite & PP & Exfoliated and intercalated & {$[101]$} \\
MMT & PP & Exfoliated & {$[114]$} \\
\hline
\end{tabular}

\subsubsection{Surface-Initiated Controlled/Living Radical Polymerization (SI-CLRP)}

Traditional in-situ polymerization methods involve the initial swelling of layered silicates within a monomer to enable the formation of the polymer within the monomer-clay sheets; the polymerization process can be initiated by heat or radiation, and simply by the diffusion of a suitable initiator or catalyst [41]. The surface-initiated controlled/living radical polymerization ${ }^{\circledR}$ (SI-CLRP) method improved the polymerization process by which exfoliation could be facilitated by polymer chains growing from nanoclay filler surfaces, leading to finely-dispersed polymer composites [115]. SI-CLRP delivers an excellent way to ensure and maintain the random dispersion of the single-clay layers and, simultaneously, provide more control over the polymer properties, such as molecular weight, dispersity, functionality, topology, and architecture [116]. Compared to conventional free radical polymerization, controlled radical polymerization minimizes side reactions and allows the synthesis of unprecedented functional polymers with narrow molecular weight distributions while retaining the tolerance of fiberglass reinforced polymers to various reaction conditions. In the SI-CLRP process, polymerization initiators (silane coupling agents, organic salts) are commonly immobilized between the clay layers by replacing the cations of the clay surface. During this polymerization step, the clay layers are highly exfoliated and dispersed [117]. A variety of novel SI-CLRP methods have been developed to improve the properties of synthesized polymer/nanoclay composites, including nitroxide-mediated polymerization (NMP), atom transfer radical polymerization (ATRP), reversible addition-fragmentation chain transfer (RAFT) polymerization, ring-opening polymerization (ROP), ring-opening metathesis polymerization (ROMP), living anionic polymerization and living cationic polymerization [118]. SI-CLRP has proven to be the most efficient approach in the preparation of core-shell polymer/nanoclay composites, enabling precise control over the structural parameters of the tethered polymer chains, thus significant technological improvements have emerged since the introduction of the CLRP method over the past 20 years [119].

Hui et al. [120] provided a comprehensive review of the materials obtained by SI-CLRP and their applications, particularly focusing on ATRP. Their study noted that ATRP has been applied for the synthesis of polymer/nanoclay composites, allowing precise control over the particle brush architectures with various polymers. Hou et al. [121] grafted amphiphilic polymer brushes on the surface of halloysite nanoclay via a RAFT method and studied the Pickering emulsification behavior of the composite in a water/soybean oil diphase mixture. Le-Masurier et al. [122] proposed a novel approach to graft PS from polydopamine-coated silica particles by RAFT grafting. The approach indicated a significant high grafting density. Utama et al. [123] pioneered a combined polymerization approach (inverse miniemulsion periphery RAFT) for the synthesis of hollow polymer/nanoclay composites, which was a promising material for water-soluble drug delivery applications. Their approach provided a reaction-free interior for the loading of drugs and allows one to readily tune the shell thickness. Nikolaidis et al. [124] prepared poly(methyl methacrylate)/ MMT composite materials by the in-situ radical bulk polymerization method. The obtained composites exhibited enhanced storage modulus and mechanical properties. Beyazit et al. [125] reviewed the various advantages arising from the use of CLRP in synthesizing molecularly imprinted polymers, in terms of sheer binding properties and their remarkable potential for post-polymerization functionalization. 


\subsubsection{Controlled Radical-Mediated Photopolymerization (P-CRP)}

The use of light to mediate controlled radical polymerization has emerged as a powerful strategy for novel polymer/nanoclay composite fabrication. Generally, controlled radical-mediated photopolymerization (P-CRP) can be divided into two different categories, namely intramolecular photochemical processes and photoredox processes [126]. There are a number of synthesis subcategories based on perspectives of the specific reagents, catalysts, and reaction mechanisms [127]. The P-CRP method utilizes low-cost and ubiquitous light sources as external regulators to prepare polymer/nanoclay composites. The method offers various potential advantages in applications such as photo-responsive gel design, particle preparation, surface fabrication, and continuous flow technology [127]. It enables the preparation of polymer/nanoclay composites with well-controlled molecular weights and topology, and provides rapid polymerization rates at relatively low temperatures [42]. Thus, the P-CRP method has attracted growing interest in recent years. A number of updated reviews have been published to discuss the P-CRP method with a focus on reagents, catalysts, applications, reaction mechanisms, polymer backbones and light sources [126-132].

Jiassi et al. [133] prepared exfoliated poly(glycidyl methacrylate)/nanoclay composites via P-CRP using thiolated-bentonite as a chain transfer agent. The synthesized composites exhibited superior thermal and mechanical properties. In the following year, the group applied the similar P-CRP method to synthesize poly(glycidyl methacrylate)/nanoclay composites. The results depicted a highly exfoliated structure and the modified nanoclay performed as a hydrogen donor for benzophenone [134]. Xie et al. [135] prepared polymer/nanoclay composites by intercalating triacrylated siloxane in cetyltrimethylammonium bromide-modified MMT layers prior to performing thiol-ene polymerization reactions by exposure to a light source. Vo et al. [38] developed a novel in-situ photo-induced SI-ATRP method to prepare intercalated poly(propargyl methacrylate)/nanoclay composites using click chemistry. Ohtsuki et al. [136] implemented the P-CRP process using a wide range of wavelengths $(350-750 \mathrm{~nm})$ to design a finely responsive polymerization system. Their study demonstrated "one-pot" selective regulation of P-CRP by simply altering the irradiation wavelength. Shanmugam et al. [137] prepared various stereo-polymers using an advanced photoinduced electron transfer-reversible addition-fragmentation chain transfer (PET-RAFT) process. This method delivered excellent control of tacticity, dispersity, molecular weight and dispersity compared with the thermal polymerization system. Chen et al. [138] developed a simple flow reactor for P-CRP processes, which enabled the process to generate trithiocarbonates (TTCs) along with significant enhancements in scalability and reaction rates compared with batch reactions. The study also demonstrated the "on/off" photo-switchability of the P-CRP process under various flow conditions. The P-CRP method delivered a promising synthesis approach for polymer/nanoclay composites with spatiotemporal control and unprecedented levels of functionality using light as an external stimulus.

\subsubsection{Click Coupling Chemistry}

Click chemistry has been used as an efficient and versatile method for the chemical modification of nanoclay surfaces [48]. Generally, click coupling reactions for polymer nanoclay synthesis, such as copper(I)-catalyzed alkyne-azide cycloaddition (CuAAC), metal-free click, Diels-Alder (DA) reaction, radical and nucleophilic thio-lene reactions, and thiol-yne reaction, require the presence of complementary functional groups on both the polymer and nanoclays [139]. Incorporating click chemistry with other synthesis methods benefits from the versatility and robustness of both these methods and may provide innovative and effective routes for the design of advance polymer-nanoclay composites with improved physicochemical properties. For instance, click chemistry has been effectively used to functionalize the end-group or pendant groups of polymers and to construct well-defined polymers with CLRP [140]. Yadav et al. [141] applied click-coupling chemistry methods to link cellulose and nanoclays covalently. The covalent linkage between modified cellulose and nanoclay was achieved using $\mathrm{Cu}(\mathrm{I})$ catalyzed azide-alkyne. Their approach enhanced the interfacial interaction between cellulose and nanoclay, which may result in improvements in the mechanical 
properties of the composite. Zhang et al. [142] developed a new hybrid halloysite nanoclay grafted by polyfluorenes using a click-coupling chemistry method, delivering a high grafting degree of polyfluorenes $(150 \%)$ due to the high productivity and a relatively small number of side relations. Zou et al. [143] concluded that click-chemistry reactions, including selective and orthogonal reactions under mild conditions, had the potential to generate real stimuli not only in developing bioactive materials of choice, but also in making the leap to the industrial scale build-up of multifunctional products such as polymer-nanoclay composite scaffolds. Pan et al. [144] developed a versatile approach based on facile thermal-triggered thiol-ene interfacial click-chemistry reactions for the preparation of nitrile butadiene rubber (NBR)/attapulgite nanoclay composites. The results indicated that the composites could be produced via the thiol-ene interfacial click reaction with excess NBR and potential use in the rubber industry.

\subsubsection{Miniemulsion Polymerization}

Miniemulsion polymerization allows composites to generate from polymerization within monomer droplets $(50-500 \mathrm{~nm})$ [119]. Ultrasonication is commonly applied in polymerization processes, but it is energy consuming. Very recently, various low-energy methods have been introduced, including in-situ surfactant generation and the use of $\mathrm{CO}_{2}$ [145]. The miniemulsion methods show advantages over other polymerization methods, such as being free of harmful solvents, high monomer conversion, and high molecular weight. Moreover, the nucleation step in miniemulsion is not as complex as in emulsion polymerization [146]. Thus, miniemulsion has been incorporated into the CLRP method to encapsulate both nonexfoliable and exfoliable nanoclays and provide excellent dispersion [147]. Depending on droplet/particle sizes and reactant concentrations, miniemulsion CLRP, such as NMP miniemulsion, ATRP miniemulsion, and RAFT miniemulsion, may be accompanied by the effects of compartmentalization [119].

Chanra et al. [148] applied the miniemulsion polymerization method to fabricate a hybrid latex composite film using a combination of poly(methyl methacrylate-co-butyl acrylate) (PMMBA) with MMT nanoclays. Miniemulsion using larger amounts $(>8.0 \mathrm{wt} \%)$ of nanoclays delivered an effective way to disperse the MMT, which led to high latex viscosity, particle size, and a relatively high amount of coagulum. The synthesized film has the potential to benefit the paper and board industries that produce high quality barrier paper for food packaging. Buruga et al. [149] utilized ultrasound-assisted miniemulsion polymerization in order to fabricate PMMA/halloysite nanoclay composites. The incorporation of ultrasonication in the miniemulsion process improved the dispersion of nanoclays in the polymer matrix, and led to enhanced mechanical and thermal properties. Chakrabarty et al. [43] reported an alternative for the preparation of fluorinated copolymer/nanoclay composites using a cationic reversible RAFT-assisted Pickering miniemulsion method (inverse miniemulsion RAFT). This novel synthesis approach increased the polymerization rate drastically. The miniemulsion (emulsion size around 200 and $300 \mathrm{~nm}$ ) step resulted in spherical copolymer/laponite particles, which had significantly low surface energies. Thus, the fabricated composite was expected to be a candidate for hydrophobic coating and fire retardance applications. The inverse miniemulsion CLRP (ATRP and RAFT) method has been a prominent focus of recent research efforts [119].

\section{Application}

Novel applications of advanced polymer/nanoclay composites have emerged in recent years, due to their superior engineering properties such as low density, high damping, high specific strength and stiffness, high fatigue endurance, and enhanced thermal behavior (Figure 5) [53]. Approximately $75-80 \%$ of the polymer/nanoclay composites are implemented in the automotive, aeronautical, and packaging industries. Companies are investing billions of dollars per annum in developing novel polymer/nanoclay composite materials [150]. This paper presents an overview of recent advances and applications of polymer/nanoclay composites with a focus on applications in the biomedical industry, rheology modification, food packaging, and wastewater pretreatment. 


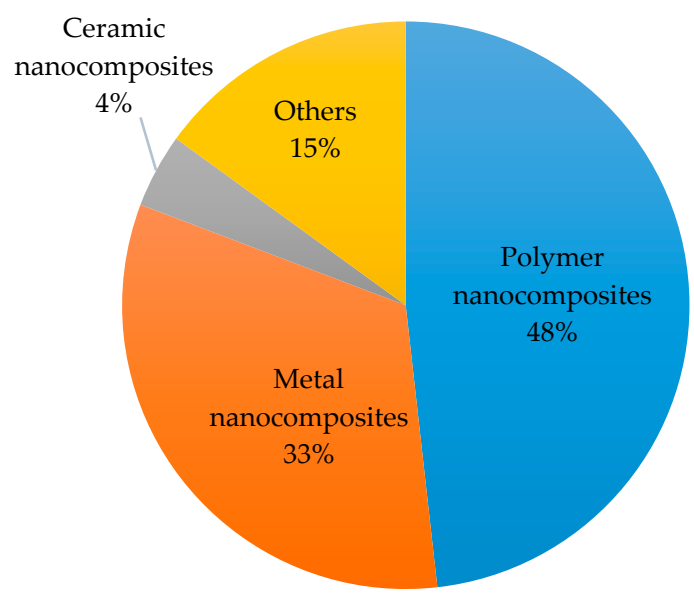

Figure 5. The publication statistics related to various types of nanocomposites out of a total of 2725 publications-topic: "nanocomposites and applications" [151].

\subsection{Rheological Control Agent}

The rheology of polymer/nanoclay composites is of great relevance to the development of advanced products with application in various fields such petroleum and pharmacy [152]. Most petroleum-based polymers are not compatible with nanoclay materials due to differences in surface energies, thus surfactants are used to reduce the surface energy of clay layers [9]. Nanoclay composites are used in a number of novel applications, such as in asphalt mixtures, where they improve the rutting and fatigue resistance of asphalt mixtures, and enhance the storage stability and the aging resistance of polymer-modified asphalt mixtures [153]. Guo et al. [154] applied nanoclay assisted by surfactants as a stabilizer in $\mathrm{CO}_{2}$ foam; according to the results, nanoclay improved the stability and formability of $\mathrm{CO}_{2}$ foam, which led to improved oil recovery from a homogeneous porous medium in a microfluidic device. The success of the implementation of surfactant/nanoclay composites as a foam stabilizer points to the petroleum industry and enhanced oil recovery as potential areas of application for these composites. Pan et al. [155] improved the rheological properties and resistivity of synthetic-based drilling fluids for high temperature applications via the use of nanoclay composites. The yield point and shear stress of the fluids were significantly increased, and the electrical resistivity of the drilling fluids was decreased by approximately $30 \%$ via the addition of $1 \%$ of nanoclay composites. By applying bentonite nanoclays to asphalt mixtures, Dong et al. [156] improved the initial strength, cracking resistance of asphalt mixtures and reduced their susceptibility to moisture. Nanoclay composites are the primary materials applied in asphalt construction [157]. Rutherford at al. [158] studied nanoclay composites emulsified asphalt mortar as a damping material for a ballastless high-speed rail track bed. The properties of modified asphalt mortar were examined, including its uniaxial compressive strength, indirect tensile strength, tensile strength ratio, dynamic modulus, phase angle, and shrinkage. The results showed that unlike concrete and asphalt, asphalt mortar emulsified with nanoclay composites exhibited properties that depend on the loading rate and temperature.

\subsection{Food Packaging}

Polymer/nanoclay composites act as a barrier against the permeation of many gases, such as oxygen, carbon dioxide, water vapors and volatile compounds (flavors and taints); this gas barrier property, along with its basic mechanical, optical and thermal properties, makes these composites excellent candidates for food packing materials [53]. In recent decades, as a result of their advantages over other conventional materials (such as plastics), a variety of polymer/nanoclay materials have been developed with reduced permeability to gases and improved thermal and mechanical properties [150]. Innovative polymer/nanoclay composites may also be designed as an intelligent packaging material to control permeability to select gases, such as $\mathrm{CO}_{2}$ and $\mathrm{CH}_{4}$, thereby extending the shelf life of preserved 
food [159]. The US military in collaboration with NASA [160], applied nanoclays as barrier enhancers for ethylene vinyl alcohol (EVOH) to develop an long-shelf-life packaging material (nonrefrigerated food). The developed material using EVOH/nanoclay composites has a shelf life of three to five years without refrigeration.

Yahiaoui et al. [161] developed an antimicrobial food packaging material using poly(e-caprolactone) (PCL)/nanoclay composites with mainly intercalated structures. It inhibited about $90 \%$ of the growth of Escherichia coli and Staphylococcus aureus, and significant reduced water vapor permeability (WVP) values up to $56 \%$. Savas et al.[162] investigated the antibacterial activity of low-density polyethylene (LDPE)/Silver-MMT nanoclay films on negative E. coli bacteria. Films with $5 \%$ of Ag+ cetyltrimethylammonium bromide (CATB) content exhibited an excellent E. coli growth inhibition (70\% reduction). Jafarzadeh et al. [163] introduced nanokaolin into semolina protein film, which resulted in a significant enhancement of the film's barrier properties (antioxidant properties) and tensile strength. Murima et al. [164] evaluated the significance of nanoclay content on the water vapor barrier behavior and optical properties of PSBA-MMT nanoclay films. The best optical properties were achieved with latex-clay 30:70 films, which decreased the light transmittance by $15 \%$. Behroozi et al. [165] prepared a mixed membrane using poly(ether-b-amide)/MMT nanoclay composites and evaluated the gas permeation properties at different pressure and clay loadings. The results indicated that the composite material helped decrease the $\mathrm{CO}_{2}$ permeation and increase the permselectivity of $\mathrm{CO}_{2} / \mathrm{CH}_{4}$ and $\mathrm{CO}_{2} / \mathrm{H}_{2}$. The permeation of soluble $\mathrm{CO}_{2}$ gas was reduced by $28 \%$ for the highest clay loading and the $\mathrm{CO}_{2} / \mathrm{CH}_{4}$ selectivity was improved to 9 at $6 \mathrm{wt} \%$ clay loading at all pressures. Raine et al. [166] developed a laminate with an exceptional gas barrier property using polyamide 11 /graphene composites. The laminate film reduced permeability to $\mathrm{CO}_{2}$ by more than one order of magnitude and reduced $\mathrm{H}_{2} \mathrm{~S}$ permeability to an undetectable level. Cherif et al. [167] studied the diffusion behavior of Irganox ${ }^{\circledR} 1076$ antioxidant (BASF, Ludwigshafen, Germany) in a novel food contact packaging film consisting of high-density polyethylene (HDPE)/cloisite ${ }^{\circledR} 15 \mathrm{~A}$ (BYK Additives \& Instrument, Wesel, Germany) nanoclay composites. The diffusion coefficients were determined according to Fick's law, which showed that the maximum diffusion rate reduction of the antioxidant reached $78 \%$ with a three $\mathrm{wt} \%$ nanoclay loading. The composite material delivered great potential for the plastic packaging industry. Soltani et al. [168] applied the sequential buildup of the layer-by-layer (LBL) surface coating strategy in food packaging applications; this strategy was considered inexpensive, effective, facile and eco-friendly. The LBL coating was prepared using a polyanion, deposited on a hydrophobic styrenic copolymer. This material reduced permeability to oxygen and $\mathrm{CO}_{2}$ substantially. Ebrahimi et al. [169] investigated the effect of a PE/closite 20A nanoclay composite film on the quality-related parameters of mature peaches. The film had a selectable barrier property that allowed fruit respiration and inhibited bacterial growth. Peaches protected by the film exhibited lower polyphenol oxidase and higher peroxidase and catalase activities than the others. Kim et al. [170] developed a multilayer packaging film coated with polyvinyl alcohol (PVA)/vermiculite nanoclay composites, and investigated the potential implications of the film for food with high moisture contents. The study showed that the oxygen permeability increased when the humidity was over $60 \%$. This effect was reversible without any deterioration of the oxygen barrier property. Yussuf et al. [171] developed a biodegradable packaging film using PP/MMT nanoclays with a pro-degradant additive. The advanced film delivered a high oxo-biodegradation rate and increasing MMT content (one to three parts per hundred), and improved the mechanical and thermal properties of the film, but was detrimental to the degradation process. Makaremi et al. [172] prepared pectin/nanoclay biocomposite films filled with two different types of halloysite nanoclays. In this study, halloysite nanoclays significantly improved the thermal, tensile, and contact angle properties of the biocomposite films. Moreover, the synthesized pectin/nanoclay biocomposite films exhibited an antimicrobial property against four different strains of Gram-positive and Gram-negative bacteria, which indicated its promising potential in the food packaging industry. 
The use of polymer/nanoclay composites in food packaging is still a developing area of research. A variety of newly-developed, low-cost materials are continuously being introduced, providing significant enhancements and relatively simple processability.

\subsection{Biomedical Applications and Drug Delivery}

Advanced nanotechnologies and innovative polymer materials with outstanding properties such as flame retardancy, mechanical, barrier, and thermal properties, have helped create advanced materials at a tremendously fast rate [150]. Cellular interactions with polymer/nanoclay composites have been the subject of recent investigations with a focus on their potential uses in biomedical applications, such as tissue engineering, gene therapy, food preservation, biosensing, bioimaging, and drug delivery [173] (Figure 6). This growing interest is due to the unique properties of polymer/nanoclay composites, including their swelling and rheological properties, high retention capacities, large surface-area-to-volume ratio and affinity for interaction with biopolymers [174]. Tissue engineering is a vital field due to the growth of the aging population and prevalence of chronic diseases. Polymer/nanoclay composites may help to repair and/or replace damaged tissue/organs [175]. For example, polymer/nanoclay-based scaffolds have been successfully implemented in cell-transplantation applications in neural tissue engineering prepared with several advanced strategies and exhibit a high degree of porosity, biocompatibility, and biodegradability [176178]. The loading amount of nanoclay in the composite matrix has a substantial effect on the storage and elastic modulus of scaffolds [179-181]. Moreover, the incorporation of nanotechnology in polymer/clay composites provides strong antibacterial properties, which significantly improves the degradation rate [182-185]. Pierchala et al. [186] developed an antibacterial, multilayered polylactic acid/halloysite nanoclay composite membrane encapsulated with gentamicin. A significant enhancement of the membrane's thermal stability and mechanical properties was observed after the incorporation of halloysite nanoclays. The synthesized composite membrane contained porous structures, which indicated its potential use in bone regeneration applications. Jin et al. [187] integrated three dimensional (3D) bioprinting technology to develop a novel, self-supporting, 3D hydrogel/laponite nanoclay composite as an internal scaffold material. The addition of laponite nanoclay effectively improved the mechanical and biological properties of the hydrogel composites, which resulted in a significant increase in the Young's modulus of the scaffold. Sheikhi et al. [188] discussed fundamental insights into polymer/nanoclay hydrogels in biomedical applications, which paved the way for the design of clay-based hydrogel scaffold materials. They investigated the effect of salts $(\mathrm{NaCl})$ and $\mathrm{CaCl}_{2}$ ) on structure and properties of the composites. Li et al. [189] synthesized an ultra-stiff and thermo-responsive hydrogel material using poly( $\mathrm{N}$-isopropylacrylamide)/nanoclay composites. The developed hydrogel exhibited a high tensile modulus (approximately $3500 \mathrm{kPa}$ ) and strength (approximately $1700 \mathrm{kPa}$ ), as well as well-defined, thermo-responsive swelling/deswelling behavior, and may potentially be used as a scaffold material. Noori et al. [190] developed a smart composite hydrogel for wound dressing using polyvinyl alcohol/chitosan/honey/clay. The exfoliated nanoclay helped improved the swelling properties and honey-releasing rate of the material. The hydrogel exhibited more than 99\% antibacterial activity. Luo et al. [191] synthesized 3D-printed oligomeric poly(propylene fumarate) (PPF) scaffolds, which were observed to be non-toxic to both human mesenchymal stem cells and L929 mouse fibroblasts. 


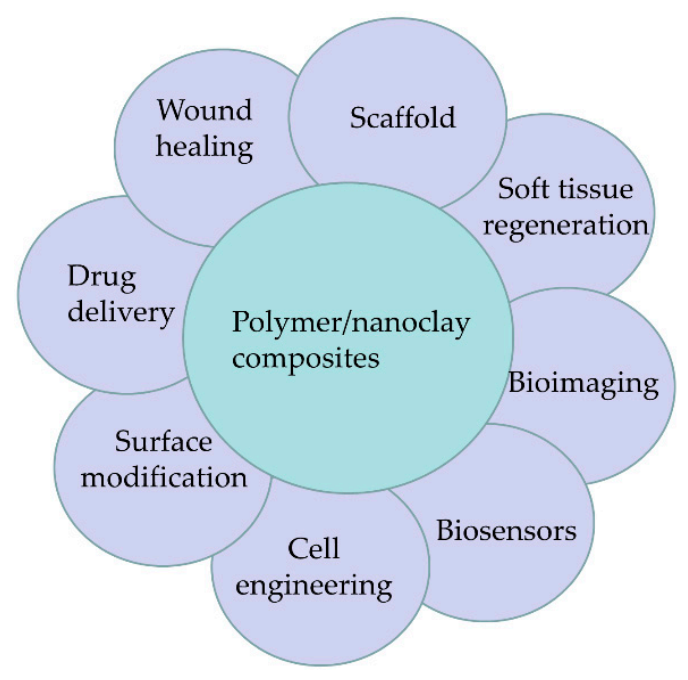

Figure 6. Various biomedical applications of polymer/nanoclay composites.

Polymer/nanoclay composites also have promising potential in other fields of the biomedical industry such as bioimaging, wound healing, in bio-sensors and as drug delivery agents. Recently, a number of polymer/nanoclay composites have been developed as contrast agents for a variety of bioimaging techniques, including magnetic resonance imaging (MRI), photoacoustic (PA) imaging, fluorescence imaging (FI), and X-ray computed tomography (CT) scan, due to their impact on bio-distribution and pharmacokinetics [151]. Lin et al. [192] developed a novel theragnostic agent using polydopamine $/ \mathrm{Fe}_{3} \mathrm{O}_{4}$ composites with promising properties such as high fluorescence quenching efficiency and near infrared absorption. It may be used in a variety of bioimaging systems including PA, MRI, and mRNA detection imaging. Due to their synergistic effects and hybrid properties, the development of polymer/nanoclay composite biosensors has gained significant interest in various applications [193], including food product analysis [194], the detection of human and animal pathogens [195], and environmental monitoring [196]. However, there are still some compatibility challenges in the implementation of polymer/nanoclay composites as a biosensor [197-199]. Kong et al. [200] developed a convenient and fast biosensor to detect glucose in human whole blood using a graphene/PANI/AuNPs/ glucose oxidase enzyme (GOx) modified screen-printed carbon electrode (SPCE). The sensor is covered by sample-impregnated paper disks. Recently, Turkmen et al.[201] incorporated platinum nanoparticles (PtNPs) into polymer/nanoclay composites for the direct sensing of glucose, which have been used for blood glucose monitoring in human blood serum samples.

Polymer/nanoclay composites have been developed to be effective vehicles for drug delivery [150]. They have efficient multifunctional properties needed for both targeting and controlling the delivery of the entrapped anticancer and antimicrobial drugs [202]. Biodegradable polymer/nanoclay composites loaded with anticancer agents can be tailored efficiently to deliver the desired therapeutic doses to target tissues/organs, thereby enhancing the agent's antitumor efficacy [203]. Gorrasi et al. [204] applied halloysite nanoclays as fillers in biodegradable poly( $\epsilon$-caprolactone) matrix and investigated the release mechanisms of sodium benzoate from the poly( $\epsilon$-caprolactone)/nanoclay composite. The addition of halloysite nanoclay enhanced the elastic modulus and mitigated the thermal degradation of the composites. The results showed that sodium benzoate molecules can be removed effectively via a washing procedure, thereby enabling the relatively accurate control of the drug's release kinetics from the composites. Saha et al. [205] conducted an in-vitro drug release study of the controlled transdermal drug delivery of methylcellulose/pectin/MMT (MC/PEC/MMT) nanoclay composite films. The results showed that the rate of release of the drug decreases with the addition of pectin and nanoclay in methylcellulose matrix. The best performance, in terms of the controlled release of a transdermal drug, was achieved in the case of five $w \mathrm{t} \%$ MMT-loaded MC/PEC/MMT nanoclay films. Othman et al. [206] applied poly(D,L-lactide)/MMT nanoclay composites as drug carriers. The incorporation of 
nanoclays into the poly(D,L-lactide) matrix improved both the drug loading capacity and the drug encapsulation efficiency. It also accelerated the rate of drug release into simulated intestinal fluid. Two $\mathrm{wt} \%$ poly(D,L-lactide)/nanoclay was observed to be the most suitable drug carrier due to the spherical shape of the composites and the almost complete inclusion of the nanoclay platelets inside the host polymer. Elsayed et al. [207] prepared a PP/MMT nanoclay composite fiber using the melt-spinning technique for Ibuprofen delivery. The prepared fiber was thermally stable, had improved mechanical properties, and low water absorption due to the high degree of homogeneity of the nanoclay in the polymer matrix. Ibuprofen was loaded in the composite fibers and approximately $33 \%$ of the loaded drug was released from the fibers during the first hour from the release time. Pacelli et al. [208] fabricated a double network hydrogel incorporating synthetic Laponite nanoclays and gellan gum. The developed stretchable and tough hydrogel is a novel drug delivery platform, exhibiting an improved swelling ratio in deionized water, improved elasticity, and an increased adsorption of ofloxacin.

\subsection{Wastewater Treatment}

The contamination of water due to the presence of an extensive variety of toxic substances, such as heavy metals, aromatic molecules, and dyes, has become a critical problem due to potential health concerns [209]. Adsorption is a widely used technique for the removal of pollutants from water; a number of novel adsorbents have been developed in recent years [210]. Polymer/nanoclay composites are able to deliver a high adsorption capacity and an excellent life cycle for water treatment/remediation due to their easy processability, effective cation exchange, large surface area, and their relatively low cost and toxicity [211]. The adsorption performance (capacity, selectivity and reusability) is substantially affected by exchangeable cations, the nanoclay structure in the matrix, the technique employed in their modification, and the existence of water molecules between the clay layers [212,213]. Various advanced polymer/nanoclay composites have been developed and used in emerging adsorbents [211]. In addition, a number of current studies demonstrate the remediation potential and effectiveness of various synthesized polymer/nanoclay composites as promising adsorbents.

Kara et al. [214] fabricated poly(vinylimidazole) (PVI)/sepiolite nanoclay composites using an in-situ polymerization method. The synthesized composite was shown to be an effective adsorbent for $\mathrm{Hg}$ (II) in wastewater. PVI/sepiolite composites exhibited a dense, smooth surface and a uniform dispersion of nanoclay in the polymer matrix, which delivered a higher adsorption capacity compared to sepiolite alone. The optimum $\mathrm{pH}$ value for $\mathrm{Hg}(\mathrm{II})$ adsorption was observed to occur at a $\mathrm{pH}$ of six, whereas its adsorption capacity values increased with the temperature. Yildiz et al. [215] employed $\mathrm{PVI} /$ bentonite nanoclay composites in wastewater treatment to remove anionic dye remazol black $\mathrm{B}(\mathrm{RB})$ from water. The maximum adsorption $(230 \mathrm{mg} / \mathrm{g})$ was achieved at a $\mathrm{pH}$ of two. Liu et al. [216] synthesized PANI/bentonite nanoclay composites by plasma-induced polymerization to remove radioactive uranium(VI) ions from aqueous solutions. Temperature, $\mathrm{pH}$ and ionic strength had significant effects on adsorption of uranium(VI) on PANI/bentonite surfaces. The adsorption capability of the PANI/bentonite was significantly enhanced within the presence of humic acid $(\mathrm{pH}<$ 6.5). El-Korashy et al. [217] reported the development of thiourea-formaldehyde/bentonite nanoclay composites for $\mathrm{Pb}(\mathrm{II}), \mathrm{Mn}(\mathrm{VII})$ and $\mathrm{Cr}(\mathrm{VI})$ adsorption in aqueous solution. The optimum $\mathrm{pH}$ was approximately four for $\mathrm{Pb}(\mathrm{II})$ and $\mathrm{Mn}(\mathrm{VII})$, two for $\mathrm{Cr}(\mathrm{VI})$. The maximum adsorption values were 13.38, 14.81 and $4.20 \mathrm{mg} / \mathrm{g}$ for $\mathrm{Pb}(\mathrm{II}), \mathrm{Mn}(\mathrm{VII})$ and $\mathrm{Cr}(\mathrm{VI})$, respectively. Regeneration experiments indicated removal efficiencies over $90 \%$ after four successive adsorption/desorption cycles [217]. Chitosan incorporated with nanoclay adsorbents has emerged as a new class of pollutant removal technique due to its relatively low cost, natural biodegradability and nontoxicity. Moissout et al. [218] focused on developing an inexpensive and environmentally-friendly adsorbent for the removal of $\mathrm{Cr}(\mathrm{VI})$ from wastewater. A chitosan/bentonite nanoclay composite was synthesized with a $5 \%$ nanoclay loading content. An adsorption test was carried out on the wastewater from a tannery in the city of Fez in 
Morocco; the composites delivered a maximum adsorption capacity of $223 \mathrm{mg} / \mathrm{g}$ of $\mathrm{Cr}(\mathrm{VI})$ at a $\mathrm{pH}$ of five.

Several polymer-nanoclay composites are able to remove various pollutants from aqueous solutions and have been shown to be effective in water treatment processes. Safety concerns remain regarding the potential for nanoparticles to be released into the environment and cause harm via chemical transformation, biological transformation, physical transformation or aggregation, and interactions between particles and natural organic matter or biomolecules [219-221]. Consequently, the further development of such materials should consider synthesis strategies, modes of application, regeneration potential, as well as environmental and human health implications.

\subsection{Other Applications}

The improved physicochemical properties created by incorporating nanoclays into a polymer matrix may benefit a wide range of applications, such as tribological properties, gas adsorption processes and automotive and battery manufacturing industries. Ge et al. [222] investigated the impact of three silane coupling agents on the tribological properties of nitrile butadiene rubber (NBR)/bentonite clay composites. The results showed that the silane agents enhanced the adhesion force and hysteresis force of the composites and reduced the friction coefficient significantly. Thermoplastic olefin (TPO)/nanoclay composites are lighter than conventional automobile parts, have desirable mechanical properties and may be used for external automotive body parts [223]. Polycarbonate (PC)/nanoclay composites have been used in the automotive industries for use as exterior coating to resist weathering and abrasion without reducing clarity [150]. Fang et al. [224] fabricated a composite membrane using poly(vinylidene fluoride)(PVDF) with different loading amounts of MMT nanoclays. The resulting composites can be used as separators in Li-ion batteries. A composite with a 5\% nanoclay loading was electrochemically stable and had a maximum ionic conductivity of $4.2 \mathrm{mS} / \mathrm{cm}$ and a minimum interfacial resistance of $97 \Omega$. Li-ion batteries comprising PVDF/MMT nanoclay composite membranes exhibited a higher battery capacity and had a more stable cycle performance than commercial Li-ion batteries [224]. Liu et al. [225] designed two effective $\mathrm{NH}_{3}$ gas adsorbents using poly-acrylic acid (PAA) with acid-treated bentonite and untreated palygorskite separately. The two different composites were observed to have distinctive structures, which led to different $\mathrm{NH}_{3}$ adsorption performance. The acid-treated bentonite composites had an adsorption capacity of $88 \mathrm{mg} / \mathrm{g}$, while palygorskite composites had an adsorption capacity of $65.8 \mathrm{mg} / \mathrm{g}$. Moreover, the adsorption of $\mathrm{NH}_{3}$ resulted in a color change of the adsorbent, making it possible to visually predict its remaining capacity. These composites may be used in air filters, providing an effective and cheap way to remove $\mathrm{NH}_{3}$ from contaminated air. Cavallaro et al. [226] applied halloysite nanoclay composites as end-stoppers to the control release of calcium hydroxide. The composites were able to preserve calcium hydroxide from carbonation and reduce the impact of acid exposure on both the mechanical performance and $\mathrm{pH}$ alteration. The synthesized composites are a promising alternative material to protect cellulose-based papers. Smith et al. [227] developed an environmentally-friendly, flame-retardant coating using PAA/halloysite nanoclay composites to protect polyurethane foam. The study showed that the composites were able to form a halloysite nanoclay barrier to prevent mass and energy transfer during open flame tests. Moreover, the developed composite coating exhibited self-extinguishing behavior and a capability to significantly reduce the total smoke release and the peak heat release rate. It has great potential to improve the fire safety of polyurethane foams.

\section{Conclusions and Prospects}

The development of innovative polymer-nanoclay composites has resulted in novel materials with specialized properties, which are mainly dependent on the type of modified nanoclay and synthesis approach. In general, melt blending is considered to be an industrially viable, as well as an ecofriendly synthesis approach. The in-situ polymerization technique delivers more control of the synthesis process in terms of the grafted amounts of organics, the clay interlayer spacing and the dispersion of 
nanoclays in the polymer matrix. Three different synthesis methods and their impact on the structure and properties of polymer-nanoclay composites were discussed in this review. Applications of polymer-nanoclay composites have gained momentum and these composites show promise in a wide range of innovative applications. This paper presents recent developments in novel polymer-nanoclay composites with potential applications in various industries, such as petroleum, food packaging, biomedical, and wastewater treatment. Some composites exhibit excellent reinforcement characteristics for physicochemical properties of materials. The process of selecting combinations of polymer and nanoclay to design and synthesize composites appears to be without a well-established scientific principle. Thus, the theory and modeling related to the design of polymer-nanoclay composites may require additional focus to provide a better understanding of high-performance composites. The Freedonia Group [150] estimates that by 2020, the demand for novel composite materials is likely to increase to about 3.2 million tons and at a cost of US\$ 15 billion per year. Major areas of application for future novel polymer-nanoclay composites are likely to include health (biomedical applications), safety (food packaging) and the environment (biodegradable materials).

Author Contributions: Writing-original draft preparation, F.G.; writing-review \& editing, S.A. and Y.H.; visualization; Y.J.

Funding: This work is in part supported by the National Key R\&D Plan (No. 2017YFC0210202-1) and the Fundamental Research Funds for the Central Universities of China (No. 2015ZZD3).

Acknowledgments: S.A. thanks Kipp Coddington at the University of Wyoming Carbon Management Institute for our lively discussions.

Conflicts of Interest: The authors declare no conflict of interest.

\section{References}

1. Nazir, M.S.; Kassim, M.H.M.; Mohapatra, L.; Gilani, M.A.; Raza, M.R.; Majeed, K. Characteristic properties of nanoclays and characterization of nanoparticulates and nanocomposites. In Nanoclay Reinforced Polymer Composites; Springer: Singapore, 2016; pp. 35-55.

2. Müller, K.; Bugnicourt, E.; Latorre, M.; Jorda, M.; Echegoyen Sanz, Y.; Lagaron, J.M.; Miesbauer, O.; Bianchin, A.; Hankin, S.; Bölz, U. Review on the processing and properties of polymer nanocomposites and nanocoatings and their applications in the packaging, automotive and solar energy fields. Nanomaterials 2017, 7, 74. [CrossRef] [PubMed]

3. Rytwo, G.J.M. Clay minerals as an ancient nanotechnology: Historical uses of clay organic interactions, and future possible perspectives. Macla 2008, 9, 15-17.

4. Lee, S.M.; Tiwari, D. Organo and inorgano-organo-modified clays in the remediation of aqueous solutions: An overview. Appl. Clay Sci. 2012, 59, 84-102. [CrossRef]

5. Uddin, M.K. A review on the adsorption of heavy metals by clay minerals, with special focus on the past decade. Chem. Eng. J. 2017, 308, 438-462. [CrossRef]

6. Jawaid, M.; Qaiss, A.K.; Bouhfid, R. Nanoclay Reinforced Polymer Composites: Nanocomposites and Bionanocomposites; Springer: Singapore, 2016.

7. Savic, I.; Stojiljkovic, S.; Savic, I.; Gajic, D. Industrial application of clays and clay minerals. In Clays and Clay Minerals: Geological Origin, Mechanical Properties and Industrial Applications; Wesley, L.R., Ed.; Nova Science Publishers: New York, NY, USA, 2014; pp. 379-402.

8. Barton, C.D.; Karathanasis, A.D. Clay minerals. In Encyclopedia of Soil Science; Lal, R., Ed.; Taylor \& Francis: Guelph, ON, Canada, 2016; p. 276.

9. Majeed, K.; Jawaid, M.; Hassan, A.; Abu Bakar, A.; Abdul Khalil, H.P.S.; Salema, A.A.; Inuwa, I. Potential materials for food packaging from nanoclay/natural fibres filled hybrid composites. Mater. Des. 2013, 46, 391-410. [CrossRef]

10. Yu, F.; Deng, H.; Bai, H.; Zhang, Q.; Wang, K.; Chen, F.; Fu, Q. Confine clay in an alternating multilayered structure through injection molding: A simple and efficient route to improve barrier performance of polymeric materials. ACS Appl. Mater. Interfaces 2015, 7, 10178-10189. [CrossRef] [PubMed]

11. Morgan, A.B.; Gilman, J. Polymer-clay nanocomposites: Design and application of multi-functional materials. Mater. Matters 2007, 2, 20-25. 
12. Giannelis, E.P. Polymer layered silicate nanocomposites. Adv. Mater. 1996, 8, 29-35. [CrossRef]

13. Yusoh, K.; Kumaran, S.V.; Ismail, F.S. Surface Modification of Nanoclay for the Synthesis of Polycaprolactone (PCL)—Clay Nanocomposite. In Proceedings of the MATEC Web of Conferences, Penang, Malaysia, 6-7 December 2017.

14. Irshidat, M.R.; Al-Saleh, M.H. Thermal performance and fire resistance of nanoclay modified cementitious materials. Constr. Build. Mater. 2018, 159, 213-219. [CrossRef]

15. Choudalakis, G.; Gotsis, A. Permeability of polymer/clay nanocomposites: A review. Eur. Polym. J. 2009, 45, 967-984. [CrossRef]

16. Ganguly, S.; Dana, K.; Mukhopadhyay, T.K.; Parya, T.; Ghatak, S. Organophilic nano clay: A Comprehensive review. Trans. Indian Ceram. Soc. 2011, 70, 189-206. [CrossRef]

17. Öztürk, N.; Tabak, A.; Akgöl, S.; Denizli, A. Newly synthesized bentonite-histidine (Bent-His) micro-composite affinity sorbents for IgG adsorption. Colloids Surf. A Physicochem. Eng. Asp. 2007, 301, 490-497. [CrossRef]

18. Pavlidou, S.; Papaspyrides, C. A review on polymer-layered silicate nanocomposites. Prog. Polym. Sci. 2008, 33, 1119-1198. [CrossRef]

19. Liu, P. Polymer modified clay minerals: A review. Appl. Clay Sci. 2007, 38, 64-76. [CrossRef]

20. Lvov, Y.; Abdullayev, E. Functional polymer-clay nanotube composites with sustained release of chemical agents. Prog. Polym. Sci. 2013, 38, 1690-1719. [CrossRef]

21. Gaaz, T.; Sulong, A.; Kadhum, A.; Al-Amiery, A.; Nassir, M.; Jaaz, A. The Impact of Halloysite on the Thermo-Mechanical Properties of Polymer Composites. Molecules 2017, 22, 838. [CrossRef] [PubMed]

22. Lazzara, G.; Cavallaro, G.; Panchal, A.; Fakhrullin, R.; Stavitskaya, A.; Vinokurov, V.; Lvov, Y. An assembly of organic-inorganic composites using halloysite clay nanotubes. Curr. Opin. Colloid Interface Sci. 2018, 35, 42-50. [CrossRef]

23. Ambre, A.H.; Katti, K.S.; Katti, D.R. Nanoclay Based Composite Scaffolds for Bone Tissue Engineering Applications. J. Nanotechnol. Eng. Med. 2010, 1, 031013. [CrossRef]

24. Carretero, M.I.; Pozo, M. Clay and non-clay minerals in the pharmaceutical and cosmetic industries Part II. Active ingredients. Appl. Clay Sci. 2010, 47, 171-181. [CrossRef]

25. Shahidi, S.; Ghoranneviss, M. Effect of Plasma Pretreatment Followed by Nanoclay Loading on Flame Retardant Properties of Cotton Fabric. J. Fusion Energy 2014, 33, 88-95. [CrossRef]

26. Cudjoe, E.; Khani, S.; Way, A.E.; Hore, M.J.A.; Maia, J.; Rowan, S.J. Biomimetic Reversible Heat-Stiffening Polymer Nanocomposites. ACS Cent. Sci. 2017, 3, 886-894. [CrossRef] [PubMed]

27. Zhang, Y.; Choi, J.R.; Park, S.-J. Interlayer polymerization in amine-terminated macromolecular chain-grafted expanded graphite for fabricating highly thermal conductive and physically strong thermoset composites for thermal management applications. Compos. Part A Appl. Sci. Manuf. 2018, 109, 498-506. [CrossRef]

28. Thakur, V.K.; Kessler, M.R. Self-healing polymer nanocomposite materials: A review. Polymer 2015, 69, 369-383. [CrossRef]

29. Shah, R.; Kausar, A.; Muhammad, B.; Shah, S. Progression from Graphene and Graphene Oxide to High Performance Polymer-Based Nanocomposite: A Review. Polymer 2015, 69, 369-383. [CrossRef]

30. Zhang, Y.; Park, S.-J. In situ shear-induced mercapto group-activated graphite nanoplatelets for fabricating mechanically strong and thermally conductive elastomer composites for thermal management applications. Compos. Part A Appl. Sci. Manuf. 2018, 112, 40-48. [CrossRef]

31. Liu, M.; Jia, Z.; Jia, D.; Zhou, C. Recent advance in research on halloysite nanotubes-polymer nanocomposite. Prog. Polym. Sci. 2014, 39, 1498-1525. [CrossRef]

32. Abdelraheem, A.; El-Shazly, A.; Elkady, M. Synthesis and Characterization of Intercalated Polyaniline-Clay Nanocomposite Using Supercritical $\mathrm{CO}_{2}$. AIP Conf. Proc. 1968, 020027. [CrossRef]

33. Utracki, L.A. Clay-Containing Polymeric Nanocomposites; iSmithers Rapra Publishing: Shawbury, UK, 2004; Volume 1.

34. Ozkose, U.U.; Altinkok, C.; Yilmaz, O.; Alpturk, O.; Tasdelen, M.A. In-situ preparation of poly(2-ethyl-2-oxazoline)/clay nanocomposites via living cationic ring-opening polymerization. Eur. Polym. J. 2017, 88, 586-593. [CrossRef]

35. Karamane, M.; Raihane, M.; Tasdelen, M.A.; Uyar, T.; Lahcini, M.; Ilsouk, M.; Yagci, Y. Preparation of fluorinated methacrylate/clay nanocomposite via in-situ polymerization: Characterization, structure, and properties. J. Polym. Sci. Part A Polym. Chem. 2017, 55, 411-418. [CrossRef] 
36. Saad, A.; Jlassi, K.; Omastová, M.; Chehimi, M.M. Clay/Conductive Polymer Nanocomposites. In Clay-Polymer Nanocomposites; Elsevier: Cambridge, MA, USA, 2017; pp. 199-237.

37. Cherifi, Z.; Boukoussa, B.; Zaoui, A.; Belbachir, M.; Meghabar, R. Structural, morphological and thermal properties of nanocomposites poly (GMA)/clay prepared by ultrasound and in-situ polymerization. Ultrason. Sonochem. 2018, 48, 188-198. [CrossRef] [PubMed]

38. Vo, V.S.; Mahouche-Chergui, S.; Babinot, J.; Nguyen, V.H.; Naili, S.; Carbonnier, B. Photo-induced SI-ATRP for the synthesis of photoclickable intercalated clay nanofillers. RSC Adv. 2016, 6, 89322-89327. [CrossRef]

39. Guerrouache, M.; Mahouche-Chergui, S.; Chehimi, M.M.; Carbonnier, B. Site-specific immobilisation of gold nanoparticles on a porous monolith surface by using a thiol-yne click photopatterning approach. Chem. Commun. 2012, 48, 7486-7488. [CrossRef] [PubMed]

40. Georgiadou, V.; Kokotidou, C.; Le Droumaguet, B.; Carbonnier, B.; Choli-Papadopoulou, T.; Dendrinou-Samara, C. Oleylamine as a beneficial agent for the synthesis of CoFe2O4 nanoparticles with potential biomedical uses. Dalton Trans. 2014, 43, 6377-6388. [CrossRef] [PubMed]

41. Nikolaidis, A.K.; Achilias, D.S.; Karayannidis, G.P. Synthesis and Characterization of PMMA/Organomodified Montmorillonite Nanocomposites Prepared by in Situ Bulk Polymerization. Ind. Eng. Chem. Res. 2011, 50, 571-579. [CrossRef]

42. Dadashi-Silab, S.; Atilla Tasdelen, M.; Yagci, Y. Photoinitiated atom transfer radical polymerization: Current status and future perspectives. J. Polym. Sci. Part A Polym. Chem. 2014, 52, 2878-2888. [CrossRef]

43. Chakrabarty, A.; Zhang, L.; Cavicchi, K.A.; Weiss, R.A.; Singha, N.K. Tailor-Made Fluorinated Copolymer/Clay Nanocomposite by Cationic RAFT Assisted Pickering Miniemulsion Polymerization. Langmuir 2015, 31, 12472-12480. [CrossRef] [PubMed]

44. Atilla, T.M.; Johannes, K.; Yusuf, Y. In situ Synthesis of Polymer/Clay Nanocomposites by Living and Controlled/Living Polymerization. Macromol. Chem. Phys. 2010, 211, 279-285. [CrossRef]

45. Schmidt, D.; Shah, D.; Giannelis, E.P. New advances in polymer/layered silicate nanocomposites. Curr. Opin. Solid State Mater. Sci. 2002, 6, 205-212. [CrossRef]

46. Ray, S.S.; Okamoto, M. Polymer/layered silicate nanocomposites: A review from preparation to processing. Prog. Polym. Sci. 2003, 28, 1539-1641.

47. Gacitua, W.; Ballerini, A.; Zhang, J. Polymer nanocomposites: Synthetic and natural fillers a review. Maderas. Cienc. Tecnol. 2005, 7, 159-178. [CrossRef]

48. Vo, V.-S.; Mahouche-Chergui, S.; Nguyen, V.-H.; Naili, S.; Singha, N.K.; Carbonnier, B. Chemical and Photochemical Routes Toward Tailor-Made Polymer-Clay Nanocomposites: Recent Progress and Future Prospects. In Clay-Polymer Nanocomposites; Jlassi, K., Chehimi, M.M., Thomas, S., Eds.; Elsevier: Amsterdam, The Netherlands, 2017; pp. 145-197.

49. Jlassi, K.; Krupa, I.; Chehimi, M.M. Overview: Clay Preparation, Properties, Modification. In Clay-Polymer Nanocomposites; Jlassi, K., Chehimi, M.M., Thomas, S., Eds.; Elsevier: Amsterdam, The Netherlands, 2017; pp. 1-28.

50. Babu Valapa, R.; Loganathan, S.; Pugazhenthi, G.; Thomas, S.; Varghese, T.O. An Overview of Polymer-Clay Nanocomposites. In Clay-Polymer Nanocomposites; Jlassi, K., Chehimi, M.M., Thomas, S., Eds.; Elsevier: Amsterdam, The Netherlands, 2017; pp. 29-81.

51. Alexandre, M.; Dubois, P. Polymer-layered silicate nanocomposites: Preparation, properties and uses of a new class of materials. Mater. Sci. Eng. R Rep. 2000, 28, 1-63. [CrossRef]

52. Beyer, G. Nanocomposites: A new class of flame retardants for polymers. Plast. Addit. Compd. 2002, 4, 22-28. [CrossRef]

53. Gurses, A. Introduction to Polymer-Clay Nanocomposites; Pan Stanford: Singapore, 2015.

54. Fischer, H.; Gielgens, L.; Koster, T. Nanocomposites from polymers and layered minerals. Acta Polym. 1999, 50, 122-126. [CrossRef]

55. Mittal, V. Advances in Polyolefin Nanocomposites; CRC Press: Boca Raton, FL, USA, 2010.

56. Rane, A.V.; Kanny, K.; Abitha, V.K.; Patil, S.S.; Thomas, S. Clay-Polymer Composites: Design of Clay Polymer Nanocomposite by Mixing. In Clay-Polymer Nanocomposites; Elsevier: Amsterdam, The Netherlands, 2017; pp. 113-144.

57. Buruga, K.; Kalathi, J.T. A facile synthesis of halloysite nanotubes based polymer nanocomposites for glass coating application. J. Alloys Compd. 2018, 735, 1807-1817. [CrossRef] 
58. Lopez-Manchado, M.; Herrero, B.; Arroyo, M. Organoclay-natural rubber nanocomposites synthesized by mechanical and solution mixing methods. Polym. Int. 2004, 53, 1766-1772. [CrossRef]

59. Maiti, M.; Sadhu, S.; Bhowmick, A.K. Ethylene-octene copolymer (engage)-clay nanocomposites: Preparation and characterization. J. Appl. Polym. Sci. 2006, 101, 603-610. [CrossRef]

60. Hausner, J.; Ziadeh, M.; Fischer, B.; Kalo, H.; Schmid, J.; Kunz, R.; Altstädt, V.; Breu, J. Transfer batch blending, an innovative solvent/solid assisted method for melt compounding to achieve good dispersion quality for polymer-clay-nanocomposites. Compos. Sci. Technol. 2015, 114, 34-41. [CrossRef]

61. Arya, V.; Philip, L. Adsorption of pharmaceuticals in water using $\mathrm{Fe}_{3} \mathrm{O}_{4}$ coated polymer clay composite. Microporous Mesoporous Mater. 2016, 232, 273-280. [CrossRef]

62. He, F.; Lam, K.-H.; Fan, J.; Chan, L.H. Improved dielectric properties for chemically functionalized exfoliated graphite nanoplates/syndiotactic polystyrene composites prepared by a solution-blending method. Carbon 2014, 80, 496-503. [CrossRef]

63. Lago, E.; Toth, P.S.; Pugliese, G.; Pellegrini, V.; Bonaccorso, F. Solution blending preparation of polycarbonate/graphene composite: Boosting the mechanical and electrical properties. RSC Adv. 2016, 6, 97931-97940. [CrossRef]

64. Abbasian, M.; Pakzad, M.; Amirmanesh, M. Polymericaly modified clays to preparation of polystyrene nanocomposite by nitroxide mediated radical polymerization and solution blending methods. Polym. Compos. 2017, 38, 1127-1134. [CrossRef]

65. Alver, E.; Metin, A.Ü.; Çiftçi, H. Synthesis and characterization of chitosan/ polyvinylpyrrolidone/ zeolite composite by solution blending method. J. Inorg. Organomet. Polym. Mater. 2014, 24, 1048-1054. [CrossRef]

66. Ray, S.S.; Bousmina, M. Biodegradable polymers and their layered silicate nanocomposites: In greening the 21st century materials world. Prog. Mater. Sci. 2005, 50, 962-1079.

67. Krishna, S.; Pugazhenthi, G. Structural and thermal properties of polystyrene/CoAl-layered double hydroxide nanocomposites prepared via solvent blending: Effect of LDH loading. J. Exp. Nanosci. 2013, 8, 19-31. [CrossRef]

68. Nanda, R.; Sasmal, A.; Nayak, P. Preparation and characterization of chitosan-polylactide composites blended with Cloisite 30B for control release of the anticancer drug paclitaxel. Carbohydr. Polym. 2011, 83, 988-994. [CrossRef]

69. Becker, C.M.; Gabbardo, A.D.; Wypych, F.; Amico, S.C. Mechanical and flame-retardant properties of epoxy/Mg-Al LDH composites. Compos. Part A Appl. Sci. Manuf. 2011, 42, 196-202. [CrossRef]

70. Yuan, Y.; Zhang, Y.; Shi, W. A novel approach for preparing exfoliated UV-cured polymer/LDH nanocomposites via pre-exfoliated organic LDH. Appl. Clay Sci. 2011, 53, 608-614. [CrossRef]

71. Choudhury, A.; Bhowmick, A.K.; Ong, C.; Soddemann, M. Effect of various nanofillers on thermal stability and degradation kinetics of polymer nanocomposites. J. Nanosci. Nanotechnol. 2010, 10, 5056-5071. [CrossRef] [PubMed]

72. Debnath, D.; Dhibar, A.K.; Khatua, B. Studies on the morphology and properties of PMMA-organoclay nanocomposites with reference to the manufacturing techniques. Polym. Plast. Technol. Eng. 2010, 49, 1087-1094. [CrossRef]

73. Ports, B.F.; Weiss, R. One-step melt extrusion process for preparing polyolefin/clay nanocomposites using natural montmorillonite. Ind. Eng. Chem. Res. 2010, 49, 11896-11905. [CrossRef]

74. Jollands, M.; Gupta, R.K. Effect of mixing conditions on mechanical properties of polylactide/montmorillonite clay nanocomposites. J. Appl. Polym. Sci. 2010, 118, 1489-1493. [CrossRef]

75. Yarahmadi, N.; Jakubowicz, I.; Hjertberg, T. Development of poly(vinyl chloride)/montmorillonite nanocomposites using chelating agents. Polym. Degrad. Stab. 2010, 95, 132-137. [CrossRef]

76. Albdiry, M.; Yousif, B.; Ku, H.; Lau, K. A critical review on the manufacturing processes in relation to the properties of nanoclay/polymer composites. J. Compos. Mater. 2013, 47, 1093-1115. [CrossRef]

77. Dennis, H.R.; Hunter, D.L.; Chang, D.; Kim, S.; White, J.L.; Cho, J.W.; Paul, D.R. Effect of melt processing conditions on the extent of exfoliation in organoclay-based nanocomposites. Polymer 2001, 42, 9513-9522. [CrossRef]

78. Ge, T.; Kalathi, J.T.; Halverson, J.D.; Grest, G.S.; Rubinstein, M. Nanoparticle Motion in Entangled Melts of Linear and Nonconcatenated Ring Polymers. Macromolecules 2017, 50, 1749-1754. [CrossRef] [PubMed]

79. Mahdis, H.; Azam, J.-A. Morphology Development via Static Crosslinking of (Polylactic Acid/Acrylic Rubber) as an Immiscible Polymer Blend. Macromol. Mater. Eng. 2018, 303, 1700446. [CrossRef] 
80. Coativy, G.; Misra, M.; Mohanty, A.K. Microwave Synthesis and Melt Blending of Glycerol Based Toughening Agent with Poly(lactic acid). ACS Sustain. Chem. Eng. 2016, 4, 2142-2149. [CrossRef]

81. Martin, C. Twin Screw Extruders as Continuous Mixers for Thermal Processing: A Technical and Historical Perspective. AAPS PharmSciTech 2016, 17, 3-19. [CrossRef] [PubMed]

82. Cruz, S.M.; Viana, J.C. Melt blending and characterization of carbon nanoparticles-filled thermoplastic polyurethane elastomers. J. Elastomers Plast. 2015, 47, 647-665. [CrossRef]

83. Burmistr, M.V.; Sukhyy, K.M.; Shilov, V.V.; Pissis, P.; Spanoudaki, A.; Sukha, I.V.; Tomilo, V.I.; Gomza, Y.P. Synthesis, structure, thermal and mechanical properties of nanocomposites based on linear polymers and layered silicates modified by polymeric quaternary ammonium salts (ionenes). Polymer 2005, 46, 12226-12232. [CrossRef]

84. Bee, S.-L.; Abdullah, M.; Mamat, M.; Bee, S.-T.; Sin, L.T.; Hui, D.; Rahmat, A. Characterization of silylated modified clay nanoparticles and its functionality in PMMA. Compos. Part B Eng. 2017, 110, 83-95. [CrossRef]

85. Beuguel, Q.; Ville, J.; Crepin-Leblond, J.; Mederic, P.; Aubry, T. Influence of clay mineral structure and polyamide polarity on the structural and morphological properties of clay polypropylene/polyamide nanocomposites. Appl. Clay Sci. 2017, 135, 253-259. [CrossRef]

86. Moustafa, H.; Galliard, H.; Vidal, L.; Dufresne, A. Facile modification of organoclay and its effect on the compatibility and properties of novel biodegradable PBE/PBAT nanocomposites. Eur. Polym. J. 2017, 87, 188-199. [CrossRef]

87. Vassiljeva, V.; Kirikal, K.-K.; Hietala, S.; Kaljuvee, T.; Mikli, V.; Rähn, M.; Tarasova, E.; Krasnou, I.; Viirsalu, M.; Savest, N. One-step carbon nanotubes grafting with styrene-co-acrylonitrile by reactive melt blending for electrospinning of conductive reinforced composite membranes. Fullerenes Nanotub. Carbon Nanostruct. 2017, 25, 667-677. [CrossRef]

88. Ercan, N.; Durmus, A.; Kaşgöz, A. Comparing of melt blending and solution mixing methods on the physical properties of thermoplastic polyurethane/organoclay nanocomposite films. J. Thermoplast. Compos. Mater. 2017, 30, 950-970. [CrossRef]

89. Quigley, J.P.; Baird, D.G. Improved mechanical properties of organoclay/nylon 6 nanocomposites prepared via a supercritical carbon dioxide-aided, melt blending method. Polym. Compos. 2015, 36, 527-537. [CrossRef]

90. Liang, C.; Hu, C.; Zheng, Y.; Yan, K.; Zhu, X. Modification of isotactic polypropylene by silica nanocapsules via melt blending method. Polym. Compos. 2018, 39, 762-769. [CrossRef]

91. Yilmaz, B.; Doğan, S.; Çelikler Kasimoğullari, S. Hemocompatibility, cytotoxicity, and genotoxicity of poly(methylmethacrylate)/nanohydroxyapatite nanocomposites synthesized by melt blending method. Int. J. Polym. Mater. Polym. Biomater. 2018, 67, 351-360. [CrossRef]

92. Vasudeo, R.A.; Samarth, N.; Jadhav, S.; Patil, S.; Narute, S. Development in air permeability of natural rubber tire tube compound by adding variable dosage of nanoclay. Macromol. Sym. 2016, 360, 34-41. [CrossRef]

93. Paci, M.; Filippi, S.; Magagnini, P. Nanostructure development in nylon 6-Cloisite ${ }^{\circledR} 30 \mathrm{~B}$ composites. Effects of the preparation conditions. Eur. Polym. J. 2010, 46, 838-853. [CrossRef]

94. Ma, H.; Tong, L.; Xu, Z.; Fang, Z. Clay network in ABS-graft-MAH nanocomposites: Rheology and flammability. Polym. Degrad. Stab. 2007, 92, 1439-1445. [CrossRef]

95. Boukerrou, A.; Duchet, J.; Fellahi, S.; Kaci, M.; Sautereau, H. Morphology and mechanical and viscoelastic properties of rubbery epoxy/organoclay montmorillonite nanocomposites. J. Appl. Polym. Sci. 2007, 103, 3547-3552. [CrossRef]

96. Han, B.; Ji, G.; Wu, S.; Shen, J. Preparation and characterization of nylon 66/montmorillonite nanocomposites with co-treated montmorillonites. Eur. Polym. J. 2003, 39, 1641-1646. [CrossRef]

97. Raka, L.; Bogoeva-Gaceva, G.; Lu, K.; Loos, J. Characterization of latex-based isotactic polypropylene/clay nanocomposites. Polymer 2009, 50, 3739-3746. [CrossRef]

98. Matuana, L.M. Rigid PVC/(layered silicate) nanocomposites produced through a novel melt-blending approach. J. Vinyl Addit. Technol. 2009, 15, 77-86. [CrossRef]

99. Huang, Y.; Yang, K.; Dong, J.Y. Copolymerization of Ethylene and 10-Undecen-1-ol using a Montmorillonite-Intercalated Metallocene Catalyst: Synthesis of Polyethylene/Montmorillonite Nanocomposites with Enhanced Structural Stability. Macromol. Rapid Commun. 2006, 27, 1278-1283. [CrossRef]

100. Abedi, S.; Abdouss, M. A review of clay-supported Ziegler-Natta catalysts for production of polyolefin/clay nanocomposites through in situ polymerization. Appl. Catal. A Gen. 2014, 475, 386-409. [CrossRef] 
101. Asensio, M.; Herrero, M.; Núñez, K.; Gallego, R.; Merino, J.C.; Pastor, J.M. In situ polymerization of isotactic polypropylene sepiolite nanocomposites and its copolymers by metallocene catalysis. Eur. Polym. J. 2018, 100, 278-289. [CrossRef]

102. Salmi, Z.; Benzarti, K.; Chehimi, M.M. Diazonium Cation-Exchanged Clay: An Efficient, Unfrequented Route for Making Clay/Polymer Nanocomposites. Langmuir 2013, 29, 13323-13328. [CrossRef] [PubMed]

103. Alicia, C.; Rafael, V.G.; Inmaculada, S.; Beatriz, P. Development of a new synthetic method based on in situ strategies for polyethylene/clay composites. J. Appl. Polym. Sci. 2012, 126, 987-997. [CrossRef]

104. Zang, L.; Qiu, J.; Yang, C.; Sakai, E. Preparation and application of conducting polymer/Ag/clay composite nanoparticles formed by in situ UV-induced dispersion polymerization. Sci. Rep. 2016, 6, 20470. [CrossRef] [PubMed]

105. Herrero, M.; Núñez, K.; Gallego, R.; Merino, J.C.; Pastor, J.M. Control of molecular weight and polydispersity in polyethylene/needle-like shaped clay nanocomposites obtained by in situ polymerization with metallocene catalysts. Eur. Polym. J. 2016, 75, 125-141. [CrossRef]

106. Kherroub, D.E.; Belbachir, M.; Lamouri, S. Synthesis of poly(furfuryl alcohol)/montmorillonite nanocomposites by direct in-situ polymerization. Bull. Mater. Sci. 2015, 38, 57-63. [CrossRef]

107. Prado, B.R.; Bartoli, J.R. Synthesis and characterization of PMMA and organic modified montmorilonites nanocomposites via in situ polymerization assisted by sonication. Appl. Clay Sci. 2018, 160, 132-143. [CrossRef]

108. Sharma, S.; Poddar, M.K.; Moholkar, V.S. Enhancement of thermal and mechanical properties of poly(MMA-co-BA)/Cloisite 30B nanocomposites by ultrasound-assisted in-situ emulsion polymerization. Ultrason. Sonochem. 2017, 36, 212-225. [CrossRef] [PubMed]

109. Cardoso, R.S.; Aguiar, V.O.; Marques, M.D.F.V. Masterbatches of polypropylene/clay obtained by in situ polymerization and melt-blended with commercial polypropylene. J. Compos. Mater. 2017, 51, 3547-3556. [CrossRef]

110. Hua, J.; Liu, J.; Wang, X.; Yue, Z.; Yang, H.; Geng, J.; Ding, A. Structure and properties of a cis-1, 4-polybutadiene/organic montmorillonite nanocomposite prepared via in situ polymerization. J. Macromol. Sci. Part B 2017, 56, 451-461. [CrossRef]

111. Boukoussa, B.; Abidallah, F.; Abid, Z.; Talha, Z.; Taybi, N.; El Hadj, H.S.; Ghezini, R.; Hamacha, R.; Bengueddach, A. Synthesis of polypyrrole/Fe-kanemite nanocomposite through in situ polymerization: Effect of iron exchange, acid treatment, and $\mathrm{CO}_{2}$ adsorption properties. J. Mater. Sci. 2017, 52, 2460-2472. [CrossRef]

112. Colonna, M.; Acquasanta, F.; Gioia, C.; Celli, A. Effect of telechelic ionic groups on the dispersion of organically modified clays in bisphenol A polycarbonate nanocomposites by in-situ polymerization using activated carbonates. Express Polym. Lett. 2017, 11, 396. [CrossRef]

113. Nair, P.P.; George, K.; Jayakrishnan, N. Studies on mechanical behavior high impact polystyrene/vinyl clay nanocomposites: Comparison between in situ polymerization and melt mixing. Polym. Compos. 2017, 38, 68-76. [CrossRef]

114. Marques, M.D.F.V.; Fernandes, R.M. Influence of Polypropylene Reaction Time on the Clay Exfoliation Process by In Situ Polymerization. J. Nanosci. Nanotechnol. 2017, 17, 5095-5103. [CrossRef]

115. Hossein, R.-M.; Vahid, H.-A.; Mohammad, N.; Mehdi, S.-K. Synthesis and characterization of clay dispersed polystyrene nanocomposite via atom transfer radical polymerization. Polym. Compos. 2010, 31, 1829-1837. [CrossRef]

116. Lee, K.M.; Han, C.D. Linear Dynamic Viscoelastic Properties of Functionalized Block Copolymer/Organoclay Nanocomposites. Macromolecules 2003, 36, 804-815. [CrossRef]

117. Konn, C.; Morel, F.; Beyou, E.; Chaumont, P.; Bourgeat-Lami, E. Nitroxide-Mediated Polymerization of Styrene Initiated from the Surface of Laponite Clay Platelets. Macromolecules 2007, 40, 7464-7472. [CrossRef]

118. Ambade, A.V. Controlled radical polymerization. In Metal-Catalyzed Polymerization; CRC Press: Boca Raton, FL, USA, 2017; pp. 161-177.

119. Zetterlund, P.B.; Thickett, S.C.; Perrier, S.B.; Bourgeat-Lami, E.; Lansalot, M. Controlled/living radical polymerization in dispersed systems: An update. Chem. Rev. 2015, 115, 9745-9800. [CrossRef] [PubMed]

120. Hui, C.M.; Pietrasik, J.; Schmitt, M.; Mahoney, C.; Choi, J.; Bockstaller, M.R.; Matyjaszewski, K. Surface-Initiated Polymerization as an Enabling Tool for Multifunctional (Nano-)Engineered Hybrid Materials. Chem. Mater. 2014, 26, 745-762. [CrossRef] 
121. Hou, Y.; Jiang, J.; Li, K.; Zhang, Y.; Liu, J. Grafting Amphiphilic Brushes onto Halloysite Nanotubes via a Living RAFT Polymerization and Their Pickering Emulsification Behavior. J. Phys. Chem. B 2014, 118, 1962-1967. [CrossRef] [PubMed]

122. Le-Masurier, S.; Gody, G.; Perrier, S.; Granville, A. One-pot polymer brush synthesis via simultaneous isocyanate coupling chemistry and "grafting from" RAFT polymerization. Polym. Chem. 2014, 5, 2816-2823. [CrossRef]

123. Utama, R.H.; Drechsler, M.; Förster, S.; Zetterlund, P.B.; Stenzel, M.H. Synthesis of pH-responsive nanocapsules via inverse miniemulsion periphery RAFT polymerization and post-polymerization reaction. ACS Macro Lett. 2014, 3, 935-939. [CrossRef]

124. Nikolaidis, A.; Achilias, D. Thermal Degradation Kinetics and Viscoelastic Behavior of Poly(Methyl Methacrylate)/Organomodified Montmorillonite Nanocomposites Prepared via In Situ Bulk Radical Polymerization. Polymers 2018, 10, 491. [CrossRef]

125. Beyazit, S.; Bui, B.T.S.; Haupt, K.; Gonzato, C. Molecularly imprinted polymer nanomaterials and nanocomposites by controlled/living radical polymerization. Prog. Polym. Sci. 2016, 62, 1-21. [CrossRef]

126. Dietlin, C.; Schweizer, S.; Xiao, P.; Zhang, J.; Morlet-Savary, F.; Graff, B.; Fouassier, J.-P.; Lalevée, J. Photopolymerization upon LEDs: New photoinitiating systems and strategies. Polym. Chem. 2015, 6, 3895-3912. [CrossRef]

127. Chen, M.; Zhong, M.; Johnson, J.A. Light-Controlled Radical Polymerization: Mechanisms, Methods, and Applications. Chem. Rev. 2016, 116, 10167-10211. [CrossRef] [PubMed]

128. Yagci, Y.; Jockusch, S.; Turro, N.J. Photoinitiated Polymerization: Advances, Challenges, and Opportunities. Macromolecules 2010, 43, 6245-6260. [CrossRef]

129. Tehfe, M.; Louradour, F.; Lalevée, J.; Fouassier, J.-P. Photopolymerization Reactions: On the Way to a Green and Sustainable Chemistry. Appl. Sci. 2013, 3, 490-514. [CrossRef]

130. Lorandi, F.; Fantin, M.; Isse, A.A.; Gennaro, A.; Matyjaszewski, K. New protocol to determine the equilibrium constant of atom transfer radical polymerization. Electrochim. Acta 2018, 260, 648-655. [CrossRef]

131. Xiao, P.; Zhang, J.; Dumur, F.; Tehfe, M.A.; Morlet-Savary, F.; Graff, B.; Gigmes, D.; Fouassier, J.P.; Lalevee, J. Visible light sensitive photoinitiating systems: Recent progress in cationic and radical photopolymerization reactions under soft conditions. Prog. Polym. Sci. 2015, 41, 32-66. [CrossRef]

132. Dadashi-Silab, S.; Doran, S.; Yagci, Y. Photoinduced electron transfer reactions for macromolecular syntheses. Chem. Rev. 2016, 116, 10212-10275. [CrossRef] [PubMed]

133. Jlassi, K.; Chandran, S.; Mičušik, M.; Benna-Zayani, M.; Yagci, Y.; Thomas, S.; Chehimi, M.M. Poly(glycidyl methacrylate)-grafted clay nanofiller for highly transparent and mechanically robust epoxy composites. Eur. Polym. J. 2015, 72, 89-101. [CrossRef]

134. Jlassi, K.; Benna-Zayani, M.; Chehimi, M.M.; Yagci, Y. Efficient photoinduced In situ preparation of clay/poly(glycidyl methacrylate) nanocomposites using hydrogen-donor silane. J. Polym. Sci. Part A Polym. Chem. 2015, 53, 800-808. [CrossRef]

135. Xie, H.; Wu, Q.; Shi, W. Preparation of photopolymerized nanocomposites through intercalating multifunctional acrylated siloxane into montmorillonite. Appl. Clay Sci. 2014, 99, 164-170. [CrossRef]

136. Ohtsuki, A.; Lei, L.; Tanishima, M.; Goto, A.; Kaji, H. Photocontrolled organocatalyzed living radical polymerization feasible over a wide range of wavelengths. J. Am. Chem. Soc. 2015, 137, 5610-5617. [CrossRef] [PubMed]

137. Shanmugam, S.; Boyer, C. Stereo-, temporal and chemical control through photoactivation of living radical polymerization: Synthesis of block and gradient copolymers. J. Am. Chem. Soc. 2015, 137, 9988-9999. [CrossRef] [PubMed]

138. Chen, M.; Johnson, J.A. Improving photo-controlled living radical polymerization from trithiocarbonates through the use of continuous-flow techniques. Chem. Commun. 2015, 51, 6742-6745. [CrossRef] [PubMed]

139. Arslan, M.; Tasdelen, M. Polymer Nanocomposites via Click Chemistry Reactions. Polymers 2017, 9, 499. [CrossRef]

140. Zhang, Z.; Zhang, P.; Wang, Y.; Zhang, W. Recent advances in organic-inorganic well-defined hybrid polymers using controlled living radical polymerization techniques. Polym. Chem. 2016, 7, 3950-3976. [CrossRef]

141. Yadav, P.; Chacko, S.; Kumar, G.; Ramapanicker, R.; Verma, V. Click chemistry route to covalently link cellulose and clay. Cellulose 2015, 22, 1615-1624. [CrossRef] 
142. Zhang, H.; Zhu, X.; Wu, Y.; Song, H.; Ba, X. High-efficiency grafting of halloysite nanotubes by using $\pi$-conjugated polyfluorenes via "click" chemistry. J. Mater. Sci. 2015, 50, 4387-4395. [CrossRef]

143. Zou, Y.; Zhang, L.; Yang, L.; Zhu, F.; Ding, M.; Lin, F.; Wang, Z.; Li, Y. “Click” chemistry in polymeric scaffolds: Bioactive materials for tissue engineering. J. Control. Release 2018, 273, 160-179. [CrossRef] [PubMed]

144. Pan, C.; Liu, P. Surface Modification of Attapulgite Nanorods with Nitrile Butadiene Rubber via Thiol-Ene Interfacial Click Reaction: Grafting or Crosslinking. Ind. Eng. Chem. Res. 2018, 57, 4949-4954. [CrossRef]

145. Ballard, N.; Salsamendi, M.; Carretero, P.; Asua, J.M. An investigation into the nature and potential of in-situ surfactants for low energy miniemulsification. J. Colloid Interface Sci. 2015, 458, 69-78. [CrossRef] [PubMed]

146. Zhou, J.; Yao, H.; Ma, J. Recent advances in RAFT-mediated surfactant-free emulsion polymerization. Polym. Chem. 2018, 9, 2532-2561. [CrossRef]

147. Wang, Y.; Dadashi-Silab, S.; Matyjaszewski, K. Photoinduced Miniemulsion Atom Transfer Radical Polymerization. ACS Macro Lett. 2018, 7, 720-725. [CrossRef]

148. Chanra, J.; Budianto, E.; Soegijono, B. Synthesis of polymer hybrid latex poly(methyl methacrylate-co-butyl acrylate) with organo montmorillonite via miniemulsion polymerization method for barrier paper. J. Phys. Conf. Ser. 2018, 985, 012029. [CrossRef]

149. Buruga, K.; Kalathi, J.T. Fabrication of $\gamma$-MPS-Modified HNT-PMMA Nanocomposites by Ultrasound-Assisted Miniemulsion Polymerization. JOM 2018, 70, 1307-1312. [CrossRef]

150. Gul, S.; Kausar, A.; Muhammad, B.; Jabeen, S. Research progress on properties and applications of polymer/clay nanocomposite. Polym. Plast. Technol. Eng. 2016, 55, 684-703. [CrossRef]

151. Kumar, S.; Nehra, M.; Dilbaghi, N.; Tankeshwar, K.; Kim, K.H. Recent advances and remaining challenges for polymeric nanocomposites in healthcare applications. Prog. Polym. Sci. 2018, 80, 1-38. [CrossRef]

152. Malkin, A.Y.; Isayev, A.I. Rheology: Concepts, Methods, and Applications; Elsevier: Amsteram, The Netherlands, 2017.

153. Yang, J.; Tighe, S. A review of advances of nanotechnology in asphalt mixtures. Procedia Soc. Behav. Sci. 2013, 96, 1269-1276. [CrossRef]

154. Guo, F.; Aryana, S. An experimental investigation of nanoparticle-stabilized $\mathrm{CO}_{2}$ foam used in enhanced oil recovery. Fuel 2016, 186, 430-442. [CrossRef]

155. Pan, D.; Vipulanandan, C.; Amani, N.; Reddy, S.A.; Chockalingam, C.G. Effects of Nanoclay on the Rheological Properties and Resistivity of Synthetic Based Drilling Fluids under High Temperature. In Proceedings of the Offshore Technology Conference, Houston, TX, USA, 30 April-3 May 2018.

156. Dong, Q.; Yuan, J.; Chen, X.; Ma, X. Reduction of moisture susceptibility of cold asphalt mixture with Portland cement and bentonite nanoclay additives. J. Clean. Prod. 2018, 176, 320-328. [CrossRef]

157. You, Z.; Mills-Beale, J.; Foley, J.M.; Roy, S.; Odegard, G.M.; Dai, Q.; Goh, S.W. Nanoclay-modified asphalt materials: Preparation and characterization. Constr. Build. Mater. 2011, 25, 1072-1078. [CrossRef]

158. Rutherford, T.; Wang, Z.; Shu, X.; Huang, B.; Clarke, D. Laboratory investigation into mechanical properties of cement emulsified asphalt mortar. Constr. Build. Mater. 2014, 65, 76-83. [CrossRef]

159. Merritt, S.; Wan, C.; Shollock, B.; Patole, S.; Haddleton, D.M. Polymer/Graphene Nanocomposites for Food Packaging. Compos. Mater. Food Packag. 2018, 251-267.

160. Perchonok, M. NASA, We Have a Challenge and It's Food Packaging. Presented at 2014 Institute of Food Technologists Annual Meeting, New Orleans, LA, USA, 21-24 June 2014.

161. Yahiaoui, F.; Benhacine, F.; Ferfera-Harrar, H.; Habi, A.; Hadj-Hamou, A.S.; Grohens, Y. Development of antimicrobial PCL/nanoclay nanocomposite films with enhanced mechanical and water vapor barrier properties for packaging applications. Polym. Bull. 2015, 72, 235-254.

162. Savas, L.A.; Hancer, M. Montmorillonite reinforced polymer nanocomposite antibacterial film. Appl. Clay Sci. 2015, 108, 40-44. [CrossRef]

163. Jafarzadeh, S.; Alias, A.K.; Ariffin, F.; Mahmud, S.; Najafi, A. Preparation and characterization of bionanocomposite films reinforced with nano kaolin. J. Food Sci. Technol. 2016, 53, 1111-1119. [CrossRef] [PubMed]

164. Murima, D.; Pfukwa, H.; Tiggelman, I.; Hartmann, P.C.; Pasch, H. Novel Polymer Clay-Based Nanocomposites: Films with Remarkable Optical and Water Vapor Barrier Properties. Macromol. Mater. Eng. 2016, 301, 836-845. [CrossRef]

165. Behroozi, M.; Pakizeh, M. Study the effects of C loisite15 A nanoclay incorporation on the morphology and gas permeation properties of P ebax2533 polymer. J. Appl. Polym. Sci. 2017, 134, 45302. 
166. Raine, T.P.; Istrate, O.M.; King, B.E.; Craster, B.; Kinloch, I.A.; Budd, P.M. Graphene/Polyamide Laminates for Supercritical $\mathrm{CO}_{2}$ and $\mathrm{H}_{2} \mathrm{~S}$ Barrier Applications: An Approach toward Permeation Shutdown. Adv. Mater. Interfaces 2018, 5, 1800304. [CrossRef]

167. Ait Cherif, G.; Kerkour, A.; Baouz, T.; Pillin, I.; Grohens, Y. Investigating the diffusional behaviour of Irganox ${ }^{\circledR} 1076$ antioxidant in HDPE/Cloisite ${ }^{\circledR} 15 \mathrm{~A}$ nanocomposite-based food contact packaging films: Effect of nanoclay loading. Packag. Technol. Sci. 2018, 31, 621-629. [CrossRef]

168. Soltani, I.; Smith, S.D.; Spontak, R.J. Effect of polyelectrolyte on the barrier efficacy of layer-by-layer nanoclay coatings. J. Membr. Sci. 2017, 526, 172-180. [CrossRef]

169. Ebrahimi, H.; Abedi, B.; Bodaghi, H.; Davarynejad, G.; Haratizadeh, H.; Conte, A. Investigation of developed clay-nanocomposite packaging film on quality of peach fruit (Prunus persica Cv. Alberta) during cold storage. J. Food Process. Preserv. 2018, 42, e13466. [CrossRef]

170. Kim, J.M.; Lee, M.H.; Ko, J.A.; Kang, D.H.; Bae, H.; Park, H.J. Influence of Food with High Moisture Content on Oxygen Barrier Property of Polyvinyl Alcohol (PVA)/Vermiculite Nanocomposite Coated Multilayer Packaging Film. J. Food Sci. 2018, 83, 349-357. [CrossRef] [PubMed]

171. Yussuf, A.; Al-Saleh, M.; Al-Samhan, M.; Al-Enezi, S.; Al-Banna, A.; Abraham, G. Investigation of polypropylene-montmorillonite clay nanocomposite films containing a pro-degradant additive. J. Polym. Environ. 2018, 26, 275-290. [CrossRef]

172. Makaremi, M.; Pasbakhsh, P.; Cavallaro, G.; Lazzara, G.; Aw, Y.K.; Lee, S.M.; Milioto, S. Effect of Morphology and Size of Halloysite Nanotubes on Functional Pectin Bionanocomposites for Food Packaging Applications. ACS Appl. Mater. Interfaces 2017, 9, 17476-17488. [CrossRef] [PubMed]

173. Mousa, M.; Evans, N.D.; Oreffo, R.O.; Dawson, J.I. Clay nanoparticles for regenerative medicine and biomaterial design: A review of clay bioactivity. Biomaterials 2018, 159, 204-214. [CrossRef] [PubMed]

174. Kerativitayanan, P.; Tatullo, M.; Khariton, M.; Joshi, P.; Perniconi, B.; Gaharwar, A.K. Nanoengineered Osteoinductive and Elastomeric Scaffolds for Bone Tissue Engineering. ACS Biomater. Sci. Eng. 2017, 3, 590-600. [CrossRef]

175. Wang, X.; Jiang, M.; Zhou, Z.; Gou, J.; Hui, D. 3D printing of polymer matrix composites: A review and prospective. Compos. Part B Eng. 2017, 110, 442-458. [CrossRef]

176. Fradique, R.; Correia, T.R.; Miguel, S.P.; de Sá, K.D.; Figueira, D.R.; Mendonça, A.G.; Correia, I.J. Production of new 3D scaffolds for bone tissue regeneration by rapid prototyping. J. Mater. Sci. Mater. Med. 2016, 27, 1-14. [CrossRef] [PubMed]

177. Aranaz, I.; Gutiérrez, M.; Ferrer, M.; del Monte, F. Preparation of Chitosan Nanocompositeswith a Macroporous Structure by Unidirectional Freezing and Subsequent Freeze-Drying. Mar. Drugs 2014, 12, 5619-5642. [CrossRef] [PubMed]

178. Serrano, M.C.; Gutiérrez, M.C.; del Monte, F. Role of polymers in the design of 3D carbon nanotube-based scaffolds for biomedical applications. Prog. Polym. Sci. 2014, 39, 1448-1471. [CrossRef]

179. Hopley, E.L.; Salmasi, S.; Kalaskar, D.M.; Seifalian, A.M. Carbon nanotubes leading the way forward in new generation 3D tissue engineering. Biotechnol. Adv. 2014, 32, 1000-1014. [CrossRef] [PubMed]

180. Hamedi, M.M.; Hajian, A.; Fall, A.B.; Håkansson, K.; Salajkova, M.; Lundell, F.; Wågberg, L.; Berglund, L.A. Highly Conducting, Strong Nanocomposites Based on Nanocellulose-Assisted Aqueous Dispersions of Single-Wall Carbon Nanotubes. ACS Nano 2014, 8, 2467-2476. [CrossRef] [PubMed]

181. Mittal, G.; Dhand, V.; Rhee, K.Y.; Park, S.-J.; Lee, W.R. A review on carbon nanotubes and graphene as fillers in reinforced polymer nanocomposites. J. Ind. Eng. Chem. 2015, 21, 11-25. [CrossRef]

182. Surudžić, R.; Janković, A.; Bibić, N.; Vukašinović-Sekulić, M.; Perić-Grujić, A.; Mišković-Stanković, V.; Park, S.J.; Rhee, K.Y. Physico-chemical and mechanical properties and antibacterial activity of silver/poly(vinyl alcohol)/graphene nanocomposites obtained by electrochemical method. Compos. Part B Eng. 2016, 85, 102-112. [CrossRef]

183. Ivanova, A.; Fravventura, M.C.; Fattakhova-Rohlfing, D.; Rathouský, J.; Movsesyan, L.; Ganter, P.; Savenije, T.J.; Bein, T. Nanocellulose-Templated Porous Titania Scaffolds Incorporating Presynthesized Titania Nanocrystals. Chem. Mater. 2015, 27, 6205-6212. [CrossRef]

184. Tsuge, Y.; Moriya, T.; Shiratori, S. Porous Transition of Polyelectrolyte Film through Reaction-Induced Phase Separation Caused by Interaction with Specific Metal Ions. Langmuir 2016, 32, 7219-7227. [CrossRef] [PubMed] 
185. Dai, X.; Guo, Q.; Zhao, Y.; Zhang, P.; Zhang, T.; Zhang, X.; Li, C. Functional Silver Nanoparticle as a Benign Antimicrobial Agent That Eradicates Antibiotic-Resistant Bacteria and Promotes Wound Healing. ACS Appl. Mater. Interfaces 2016, 8, 25798-25807. [CrossRef] [PubMed]

186. Pierchala, M.K.; Makaremi, M.; Tan, H.L.; Pushpamalar, J.; Muniyandy, S.; Solouk, A.; Lee, S.M.; Pasbakhsh, P. Nanotubes in nanofibers: Antibacterial multilayered polylactic acid/halloysite/gentamicin membranes for bone regeneration application. Appl. Clay Sci. 2018, 160, 95-105. [CrossRef]

187. Jin, Y.; Liu, C.; Chai, W.; Compaan, A.; Huang, Y. Self-Supporting Nanoclay as Internal Scaffold Material for Direct Printing of Soft Hydrogel Composite Structures in Air. ACS Appl. Mater. Interfaces 2017, 9, 17456-17465. [CrossRef] [PubMed]

188. Sheikhi, A.; Afewerki, S.; Oklu, R.; Gaharwar, A.K.; Khademhosseini, A. Effect of ionic strength on shear-thinning nanoclay-polymer composite hydrogels. Biomater. Sci. 2018. [CrossRef] [PubMed]

189. Li, H.-J.; Jiang, H.; Haraguchi, K. Ultrastiff, Thermoresponsive Nanocomposite Hydrogels Composed of Ternary Polymer-Clay-Silica Networks. Macromolecules 2018, 51, 529-539. [CrossRef]

190. Noori, S.; Kokabi, M.; Hassan, Z. Poly(vinyl alcohol)/chitosan/honey/clay responsive nanocomposite hydrogel wound dressing. J. Appl. Polym. Sci. 2018, 135, 46311. [CrossRef]

191. Luo, Y.; Dolder, C.K.; Walker, J.M.; Mishra, R.; Dean, D.; Becker, M.L. Synthesis and Biological Evaluation of Well-Defined Poly(propylene fumarate) Oligomers and Their Use in 3D Printed Scaffolds. Biomacromolecules 2016, 17, 690-697. [CrossRef] [PubMed]

192. Lin, L.-S.; Cong, Z.-X.; Cao, J.-B.; Ke, K.-M.; Peng, Q.-L.; Gao, J.; Yang, H.-H.; Liu, G.; Chen, X. Multifunctional $\mathrm{Fe}_{3} \mathrm{O}_{4} @$ Polydopamine Core-Shell Nanocomposites for Intracellular mRNA Detection and Imaging-Guided Photothermal Therapy. ACS Nano 2014, 8, 3876-3883. [CrossRef] [PubMed]

193. Barsan, M.M.; Ghica, M.E.; Brett, C.M.A. Electrochemical sensors and biosensors based on redox polymer/carbon nanotube modified electrodes: A review. Anal. Chim. Acta 2015, 881, 1-23. [CrossRef] [PubMed]

194. Bahadır, E.B.; Sezgintürk, M.K. Applications of commercial biosensors in clinical, food, environmental, and biothreat/biowarfare analyses. Anal. Biochem. 2015, 478, 107-120. [CrossRef] [PubMed]

195. Krishnamoorthy, M.; Hakobyan, S.; Ramstedt, M.; Gautrot, J.E. Surface-Initiated Polymer Brushes in the Biomedical Field: Applications in Membrane Science, Biosensing, Cell Culture, Regenerative Medicine and Antibacterial Coatings. Chem. Rev. 2014, 114, 10976-11026. [CrossRef] [PubMed]

196. Knopfmacher, O.; Hammock, M.L.; Appleton, A.L.; Schwartz, G.; Mei, J.; Lei, T.; Pei, J.; Bao, Z. Highly stable organic polymer field-effect transistor sensor for selective detection in the marine environment. Nat. Commun. 2014, 5, 2954. [CrossRef] [PubMed]

197. Hu, W.; Chen, S.; Yang, J.; Li, Z.; Wang, H. Functionalized bacterial cellulose derivatives and nanocomposites. Carbohydr. Polym. 2014, 101, 1043-1060. [CrossRef] [PubMed]

198. Huang, J.; Zhu, Y.; Jiang, W.; Yin, J.; Tang, Q.; Yang, X. Parallel Carbon Nanotube Stripes in Polymer Thin Film with Remarkable Conductive Anisotropy. ACS Appl. Mater. Interfaces 2014, 6, 1754-1758. [CrossRef] [PubMed]

199. Tang, L.-C.; Wang, X.; Gong, L.-X.; Peng, K.; Zhao, L.; Chen, Q.; Wu, L.-B.; Jiang, J.-X.; Lai, G.-Q. Creep and recovery of polystyrene composites filled with graphene additives. Compos. Sci. Technol. 2014, 91, 63-70. [CrossRef]

200. Kong, F.-Y.; Gu, S.-X.; Li, W.-W.; Chen, T.-T.; Xu, Q.; Wang, W.J.B. A paper disk equipped with graphene/polyaniline/Au nanoparticles/glucose oxidase biocomposite modified screen-printed electrode: Toward whole blood glucose determination. Biosens. Bioelectron. 2014, 56, 77-82. [CrossRef]

201. Turkmen, E.; Bas, S.Z.; Gulce, H.; Yildiz, S.J.E.A. Glucose biosensor based on immobilization of glucose oxidase in electropolymerized poly(o-phenylenediamine) film on platinum nanoparticles-polyvinylferrocenium modified electrode. Electrochim. Acta 2014, 123, 93-102. [CrossRef]

202. Mishra, D.K.; Yadav, K.S.; Prabhakar, B.; Gaud, R.S. Nanocomposite for cancer targeted drug delivery. In Applications of Nanocomposite Materials in Drug Delivery; Inamuddin, A.M.A., Mohammad, A., Eds.; Woodhead Publishing: Duxford, UK, 2018; pp. 323-337. 5p.

203. Rajan, M.; Murugan, M.; Ponnamma, D.; Sadasivuni, K.K.; Munusamy, M.A. Poly-carboxylic acids functionalized chitosan nanocarriers for controlled and targeted anti-cancer drug delivery. Biomed. Pharmacother. 2016, 83, 201-211. [CrossRef] [PubMed] 
204. Gorrasi, G.; Attanasio, G.; Izzo, L.; Sorrentino, A. Controlled release mechanisms of sodium benzoate from a biodegradable polymer and halloysite nanotube composite. Polym. Int. 2017, 66, 690-698. [CrossRef]

205. Saha, N.R.; Sarkar, G.; Roy, I.; Rana, D.; Bhattacharyya, A.; Adhikari, A.; Mukhopadhyay, A.; Chattopadhyay, D. Studies on methylcellulose/pectin/montmorillonite nanocomposite films and their application possibilities. Carbohydr. Polym. 2016, 136, 1218-1227. [CrossRef] [PubMed]

206. Othman, R.; Vladisavljević, G.T.; Thomas, N.L.; Nagy, Z.K. Fabrication of composite poly(D,L-lactide)/montmorillonite nanoparticles for controlled delivery of acetaminophen by solvent-displacement method using glass capillary microfluidics. Colloids Surf. B Biointerfaces 2016, 141, 187-195. [CrossRef] [PubMed]

207. Elsharif, M.; Mohamed, W.S. Preparation and Characterization of Melt Spun Polypropylene/Montmorillonite Nanocomposite Fibre for Ibuprofen Drug Delivery application. Egypt. J. Chem. 2018, 61, 235-244.

208. Pacelli, S.; Paolicelli, P.; Avitabile, M.; Varani, G.; Di Muzio, L.; Cesa, S.; Tirillò, J.; Bartuli, C.; Nardoni, M.; Petralito, S. Design of a tunable nanocomposite double network hydrogel based on gellan gum for drug delivery applications. Eur. Polym. J. 2018, 104, 184-193. [CrossRef]

209. Pandey, S. A comprehensive review on recent developments in bentonite-based materials used as adsorbents for wastewater treatment. J. Mol. Liq. 2017, 241, 1091-1113. [CrossRef]

210. Peng, Y.; Huang, H.; Zhang, Y.; Kang, C.; Chen, S.; Song, L.; Liu, D.; Zhong, C. A versatile MOF-based trap for heavy metal ion capture and dispersion. Nat. Commun. 2018, 9, 187. [CrossRef] [PubMed]

211. Unuabonah, E.I.; Taubert, A. Clay-polymer nanocomposites (CPNs): Adsorbents of the future for water treatment. Appl. Clay Sci. 2014, 99, 83-92. [CrossRef]

212. Hernández-Hernández, K.A.; Illescas, J.; Díaz-Nava, M.C.; Muro-Urista, C.R.; Martínez-Gallegos, S.; Ortega-Aguilar, R.E. Polymer-clay nanocomposites and composites: Structures, characteristics, and their applications in the removal of organic compounds of environmental interest. Med. Chem. 2016, 6, 201-210. [CrossRef]

213. Atta, A.M.; Al-Lohedan, H.A.; Ezzat, A.O.; Issa, Z.A.; Oumi, A.B. Synthesis and application of magnetite polyacrylamide amino-amidoxime nano-composites as adsorbents for water pollutants. J. Polym. Res. 2016, 23, 69. [CrossRef]

214. Kara, A.; Tekin, N.; Alan, A.; Şafakl1, A. Physicochemical parameters of $\mathrm{Hg}(\mathrm{II})$ ions adsorption from aqueous solution by sepiolite/poly(vinylimidazole). J. Environ. Chem. Eng. 2016, 4, 1642-1652. [CrossRef]

215. Yildiz, G.; Senkal, B.F. Formation of composites between polyvinylimidazole and bentonites and their use for removal of remazol black B from water. Sep. Sci. Technol. 2016, 51, 2596-2603. [CrossRef]

216. Liu, X.; Cheng, C.; Xiao, C.; Shao, D.; Xu, Z.; Wang, J.; Hu, S.; Li, X.; Wang, W. Polyaniline (PANI) modified bentonite by plasma technique for U(VI) removal from aqueous solution. Appl. Surf. Sci. 2017, 411, 331-337. [CrossRef]

217. El-Korashy, S.A.; Elwakeel, K.Z.; El-Hafeiz, A.A. Fabrication of bentonite/thiourea-formaldehyde composite material for $\mathrm{Pb}(\mathrm{II}), \mathrm{Mn}(\mathrm{VII})$ and $\mathrm{Cr}(\mathrm{VI})$ sorption: A combined basic study and industrial application. J. Clean. Prod. 2016, 137, 40-50. [CrossRef]

218. Moussout, H.; Ahlafi, H.; Aazza, M.; El Akili, C. Performances of local chitosan and its nanocomposite 5\% Bentonite/Chitosan in the removal of chromium ions (Cr (VI)) from wastewater. Int. J. Boil. Macromol. 2018, 108, 1063-1073. [CrossRef] [PubMed]

219. Mattsson, K.; Jocic, S.; Doverbratt, I.; Hansson, L.-A. Nanoplastics in the Aquatic Environment. In Microplastic Contamination in Aquatic Environments; Zeng, E.Y., Ed.; Elsevier: Amsterdam, The Netherlands, 2018; pp. 379-399. 8p.

220. Noventa, S.; Hacker, C.; Rowe, D.; Elgy, C.; Galloway, T. Dissolution and bandgap paradigms for predicting the toxicity of metal oxide nanoparticles in the marine environment: An in vivo study with oyster embryos. Nanotoxicology 2018, 12, 63-78. [CrossRef] [PubMed]

221. McGillicuddy, E.; Murray, I.; Kavanagh, S.; Morrison, L.; Fogarty, A.; Cormican, M.; Dockery, P.; Prendergast, M.; Rowan, N.; Morris, D. Silver nanoparticles in the environment: Sources, detection and ecotoxicology. Sci. Total. Environ. 2017, 575, 231-246. [CrossRef] [PubMed]

222. Ge, X.; Zhang, Y.; Deng, F.; Cho, U.R. Effects of silane coupling agents on tribological properties of bentonite/nitrile butadiene rubber composites. Appl. Clay Sci. 2017, 38, 2347-2357. [CrossRef]

223. Miller, L.; Soulliere, K.; Sawyer-Beaulieu, S.; Tseng, S.; Tam, E. Challenges and Alternatives to Plastics Recycling in the Automotive Sector. Materials 2014, 7, 5883-5902. [CrossRef] [PubMed] 
224. Fang, C.; Yang, S.; Zhao, X.; Du, P.; Xiong, J. Electrospun montmorillonite modified poly(vinylidene fluoride) nanocomposite separators for lithium-ion batteries. Mater. Res. Bull. 2016, 79, 1-7. [CrossRef]

225. Liu, E.; Sarkar, B.; Wang, L.; Naidu, R. Copper-complexed clay/poly-acrylic acid composites: Extremely efficient adsorbents of ammonia gas. Appl. Clay Sci. 2016, 121-122, 154-161. [CrossRef]

226. Cavallaro, G.; Danilushkina, A.; Evtugyn, V.; Lazzara, G.; Milioto, S.; Parisi, F.; Rozhina, E.; Fakhrullin, R. Halloysite Nanotubes: Controlled Access and Release by Smart Gates. Nanomaterials 2017, 7, 199. [CrossRef] [PubMed]

227. Smith, R.J.; Holder, K.M.; Ruiz, S.; Hahn, W.; Song, Y.; Lvov, Y.M.; Grunlan, J.C. Environmentally Benign Halloysite Nanotube Multilayer Assembly Significantly Reduces Polyurethane Flammability. Adv. Funct. Mater. 2018, 28, 1703289. [CrossRef]

(C) 2018 by the authors. Licensee MDPI, Basel, Switzerland. This article is an open access article distributed under the terms and conditions of the Creative Commons Attribution (CC BY) license (http:/ / creativecommons.org/licenses/by/4.0/). 